\title{
New challenges for sunflower ideotyping in changing environments and more ecological cropping systems ${ }^{\text {th }}$
}

\author{
Philippe Debaeke ${ }^{1, *}$, Pierre Casadebaig ${ }^{1}$ and Nicolas B. Langlade ${ }^{2}$ \\ 1 AGIR, Université de Toulouse, INRAE, Castanet-Tolosan, France \\ 2 LIPM, Université de Toulouse, INRAE, CNRS, Castanet-Tolosan, France
}

Received 12 November 2020 - Accepted 14 April 2021

\begin{abstract}
As a rainfed spring-sown crop, sunflower (Helianthus annuus L.) is increasingly exposed to negative impacts of climate change, especially to high temperatures and drought stress. Incremental, systemic and transformative adaptations have been suggested for reducing the crop vulnerability to these stressful conditions. In addition, innovative cropping systems based on low-input management, organic farming, soil and water conservation practices, intercropping, double-cropping, and/or agroforestry are undergoing marked in agriculture. Because of its plasticity and low-input requirements (nitrogen, water, pesticides), sunflower crop is likely to take part to these new agroecological systems. Aside from current production outputs (yield, oil and cake), ecosystem services (e.g. bee feeding, soil phytoremediation...), and non-food industrial uses are now expected externalities for the crop. The combination of climatic and societal contexts could deeply modify the characteristics of genotypes to be cultivated in the main production areas (either traditional or adoptive). After reviewing these changes, we identify how innovative cropping systems and new environments could modify the traits classically considered up to now, especially in relation to expected ecosystem services. Finally, we consider how research could provide methods to help identifying traits of interest and design ideotypes.
\end{abstract}

Keywords: ideotypes / ecosystem services / agroecology / climate change / breeding

Résumé - De nouveaux défis pour la conception d'idéotypes de tournesol pour des environnements changeants et des systèmes de culture plus écologiques. En tant que culture d'été non irriguée, le tournesol (Helianthus annuus L.) est davantage exposé aux impacts négatifs du changement climatique, et en particulier aux températures élevées et au stress hydrique. Des adaptations incrémentales, systémiques ou de rupture ont été suggérées pour réduire la vulnérabilité de la culture à ces conditions stressantes. Par ailleurs, des systèmes de culture innovants sont en fort développement qu'il s'agisse de systèmes à bas niveaux d'intrants, d'agriculture biologique, d'agriculture de conservation des sols, d'agroforesterie, ou de l'introduction d'associations de cultures et de doubles cultures. En raison de sa plasticité et de ses faibles besoins en intrants (eau, azote, pesticides), la culture de tournesol est amenée à s'insérer de manière privilégiée dans ces systèmes agro-écologiques. À côté de la production (grains, huile, tourteaux), de nouvelles externalités sont attendues comme la contribution aux autres services écosystémiques (pollinisateurs, phytoremédiation...) et de nouveaux usages non alimentaires. La conjugaison des contextes climatiques et sociétaux pourrait profondément changer les caractéristiques attendues des variétés cultivées dans les principales régions de production qu'elles soient traditionnelles ou en reconquête. Après une revue de ces changements, nous identifions comment systèmes innovants et changement climatique pourraient modifier les caractères phénotypiques considérés classiquement, en particulier dans la perspective de nouveaux services. Enfin, nous verrons comment la recherche pourrait fournir des méthodes pour faciliter l'identification de ces caractères d'intérêt et aider à la conception d'idéotypes.

Mots clés : traits / idéotypes / services écosystémiques / agroécologie / changement climatique / sélection variétale

\footnotetext{
"Contribution to the Topical Issue "Sunflower / Tournesol".

*Correspondence: philippe.debaeke@inrae.fr
} 


\section{Opportunities for growing sunflower crop}

Sunflower (Helianthus annuus L.) crop is grown worldwide in temperate, subtropical and tropical climates under a wide range of agro-environments. Among oilseeds, it ranked 3rd in 2018 behind soybean and rapeseed (4th after palm, soybean and rapeseed for edible oil) with an average annual world production of about $52 \mathrm{MnT}$ (Oil World Annual, 2019). The EU-27 comes in 3rd position after Ukraine and Russia, the whole European continent producing $71 \%$ of the seeds on $67 \%$ of the acreage in sunflower worldwide.

Sunflower benefits from broad and established markets (Pilorgé, 2020). It is primarily grown for its edible oil but also for its achenes (confectionary types) both commonly used in human food. High-oleic varieties are widely appreciated by food industry because of oxidative and thermal oil stabilities (Dunford, 2015). After oil extraction, the residual cake becomes a high-protein meal for livestock (Peyronnet et al., 2014). In addition, due to the properties of sunflower oil, green chemistry and energy are two potential outlets (Park et al., 1997) while by-products utilizations have emerged in building industry (Borredon et al., 2011).

In arid and semi-arid environments, sunflower is grown under irrigation or rainfed, whereas in temperate regions it is mainly a rainfed crop (García-Vila et al., 2012). In France, where only $5 \%$ of the sunflower acreage receive supplemental irrigation, it needs only limited water amounts $(\sim 50 \mathrm{~mm})$ with a good efficiency i.e. $0.5-1.5 \mathrm{q} /$ ha of extra yield for each $10 \mathrm{~mm}$ applied around flowering (Champolivier et al., 2011). As a warm-season and intermediate water-use crop, it can add diversity to dryland crop rotations (Anderson et al., 1999; Johnston et al., 2002). Being moderately drought-tolerant, it often brings satisfactory results when other crops are dramatically impacted by drought (Debaeke and Bertrand, 2008).

Agronomically, the crop is considered by farmers as versatile, cheap, rustic and easy to manage, with rotational benefits for winter crops (Lecomte and Nolot, 2011). It is largely labelled as "environmental-friendly" in relation with its low-input requirements in water, fertilizers and pesticides and due to limited greenhouse gas emissions (Debaeke et al., 2017a, 2017b). Altogether, this makes sunflower the major oilseed crop grown in organic farms in France (Le Gall, 2019).

However, in spite of significant breeding efforts (Vear, 2016), its on-farm productivity is relatively low and stable because of a set of yield-limiting factors (e.g. birds, fungal diseases, low and uneven plant population, poor crop management) in the main production areas (Mercau et al., 2001; Grassini et al., 2009; Jouffret et al., 2011; Hall et al., 2013). Consequently, cultivated areas are stagnating or decreasing especially in Western Europe and the potential ecosystem services fulfilled by the crop do not compensate for the lack of economic competitiveness mainly attributed to low yields.

In addition, other sources of edible oil are now preferred for nutritional reasons: rapeseed and olive oils have increased their market share at the expense of sunflower oil as they provide more n-3 PUFA (polyunsaturated fatty acids) and among sunflower oils, more n-6 PUFA are provided by traditional linoleic varieties compared to high-oleic ones (Duru and Magrini, 2017; Duru, 2019). Other trade considerations have favoured the world extent of soybean and palm oils.
As stated, many breeding efforts by public and private research compensate for these drawbacks (oil quality, tolerance or resistance to fungal diseases, potential yield) and obvious genetic progress were reported in registration and demonstration trials (Vear et al., 2003; Jouffret et al., 2011; Vear, 2016).

However, the production context is now rapidly changing. New growing environments are open to sunflower with climate change (e.g. northern extension in Europe - Bellarby et al., 2010). Societal demands for more 'environmental-friendly' agriculture using less or no chemicals and preserving environmental resources (e.g. water) are clearly asserted. Beyond production, agriculture must contribute to the provision of a package of ecosystem services. All these shifts could open new avenues for sunflower as the crop through its plasticity has many cards to play in various agricultural systems (Lecomte and Nolot, 2011; Debaeke et al., 2017a, 2017b; Pilorgé, 2020). As crop management has to be deeply changed during agroecological transition, it will require a complete overhaul of the characteristics of the varieties that are currently grown (Meynard et al., 1997). The expected new traits and ideotypes should draw a sunflower crop more adapted to these new challenges both in traditional and adoptive regions.

\section{Are current varieties adapted to face these new challenges?}

Advanced lines and hybrids developed by breeders are usually subjected to multi-environment trials to evaluate their relative performance for a target population of environments. Before its commercial release, each variety in the EU undergoes VCU (Value for Cultivation and Use) trials for at least two years before entering in the National List of Plant Varieties. Thereafter, at least in France, the registered varieties are widely tested for another 2-3 years (post-registration) to identify the best performing ones under local conditions and provide descriptions of their main agronomic and technological characteristics. These trials now result in the publication of Recommended Variety Lists (Terres Inovia, 2020).

Some limitations to this experimental system have been discussed previously for France (Debaeke et al., 2011; Casadebaig et al., 2016). Although this testing network covers the main regions of sunflower production, more diverse environmental conditions (soil, weather, management) would undoubtedly improve the assessment of yield stability and would be necessary to face the more stressful conditions observed with climate change, water restrictions and diversity of cropping systems. Moreover, no sound characterization of the physical environment (e.g. available soil water) and constraints perceived by plants (as water and nitrogen stresses, disease severity) is available routinely.

Meanwhile, only a few traits are measured to assess the performance of new sunflower varieties. They are restricted to final productivity, grain quality, earliness and tolerance to major diseases (Tab. 1) which is more or less the same in the other producing countries. Although sunflower is a summer crop, grown without irrigation in shallow to moderately deep soils, no evaluation of drought tolerance is achieved even if earliness to anthesis can be considered as a drought escape trait. Therefore, current evaluation criteria do not include yield stability per se and even exclude it indirectly because the 
Table 1. Criteria available to growers in France to choose a sunflower variety. These criteria are presently included in the MyVar web tool (www.myvar.fr) developed by Terres Inovia (adapted from Casadebaig et al., 2016).

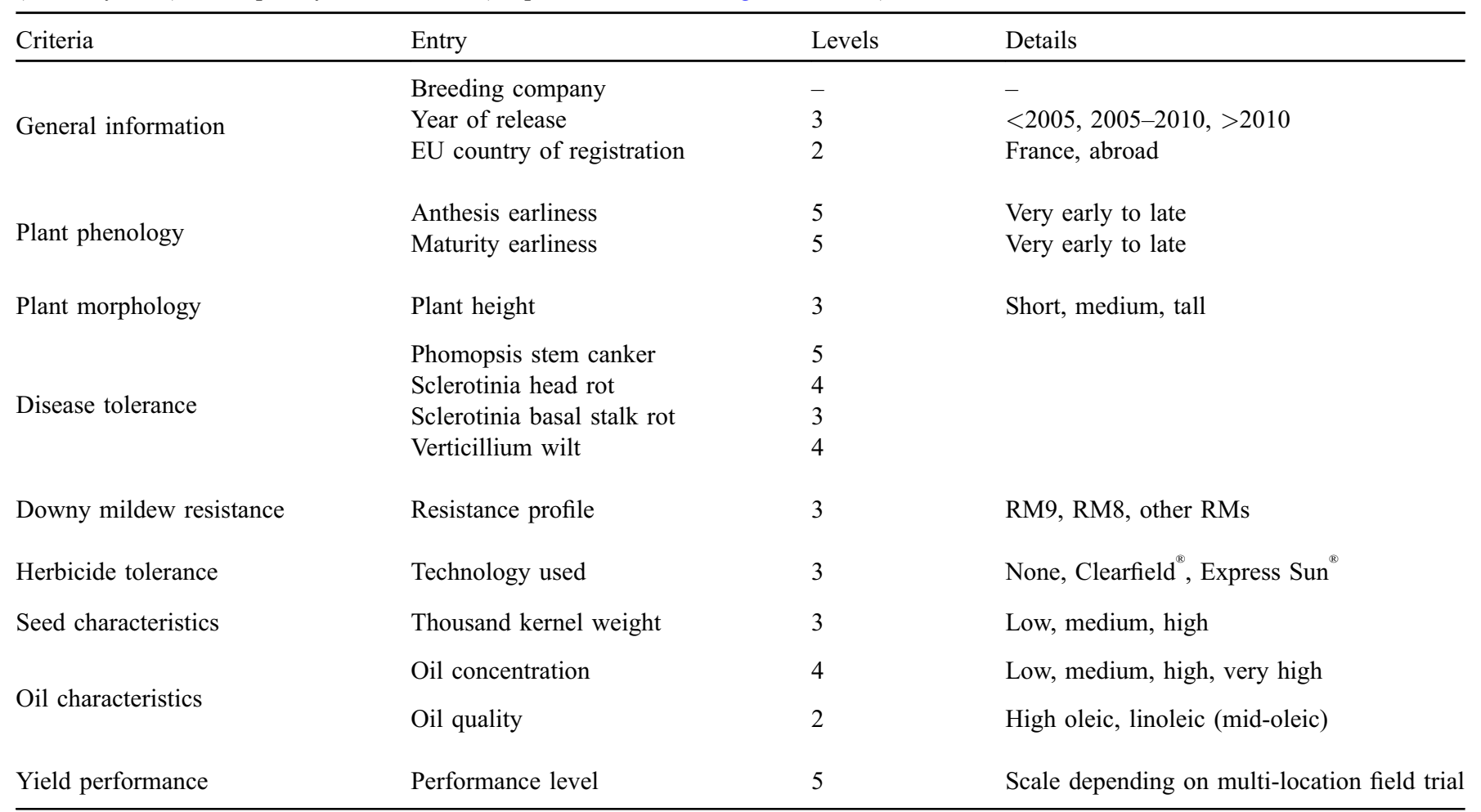

evaluation network has rather homogenous conditions that do not reflect the diversity of farming conditions such as the different water deficit scenarios observed in the vast majority of farming conditions (Debaeke et al., 2011). Moreover, current procedures prevent the registration of varieties exhibiting higher yield stability in unfavorable grower-like conditions but with a similar or lower average performance compared to check varieties in the tested high-yielding conditions.

In addition, on each site, a single crop management system is applied, independently of variety-specific requirements (e.g. plant density), which impedes the proposal of specific "varietymanagement" pairs per type of environment.

More information at least on plant architecture and response to water constraint would improve the characterization of past and future varieties and their response to a wider range of environments. This was developed in sunflower for calibrating a variety-based simulation model (SUNFLO) (Casadebaig et al., 2011). For over 100 commercial varieties, additional parameters were measured in dedicated fields (Terres Inovia) and semi-controlled platforms (INRAE) such as: leaf area index (LAI) dynamics, harvest index, response of transpiration and leaf expansion to soil water deficit (Debaeke et al., 2010; Casadebaig et al., 2008, 2016; Gosseau et al., 2019; Pinochet et al., 2020). This phenotypic database is regularly updated with new accessions.

As argued before, sunflower ideotypes have to be designed for changing environments, new cropping systems and ecosystem services. This implies that new trait measurement protocols must complete the current routine characterization done in the VCU (and post-registration) trials. They should assess non-productive ecosystem services provided by the crop with possible intra-specific variation such as melliferous potential (Cerrutti and Pontet, 2016) and test a wider range of growing conditions (water-limited conditions, organic farming). A multicriteria approach combining several breeding targets such as adaptation to environments, cropping systems, markets, and non-productive ecosystem services should be proposed for designing and evaluating the multi-performance of a variety as illustrated on Figure 1. The end-use of sunflower achenes and oil is actually determinant in the variety decision at farm level. In Europe, it concerns mainly the choice of a linoleic (classic) versus (high) oleic type, in relation with a premium paid for quality by the market. In other countries, choosing an oilseed or a confectionary type could be an option too. Among oilseed varieties, different fatty acids profiles and the content in minor components as tocopherols and phytosterols could orientate the choice towards specific varieties (Nolasco et al., 2006; Ayerdi-Gotor et al., 2015).

Hulls are a by-product of sunflower oil processing and of confectionary seeds dehulling process. The hullability and protein concentration traits are now more important to consider for meal production in animal nutrition and some variability was observed among commercial varieties (Dauguet et al., 2016). All these outcomes and the market access will orientate the information included in the recommended list of varieties with some absolute requirements (seed composition) or some preferences

In the following sections, we will discuss traits to be considered and ranked by breeders and advisers regarding new sets of constraints expected in a close future in relation with climate change (Sect. 3) and innovative cropping practices (Sect. 4). We will also propose expected outcomes of sunflower 


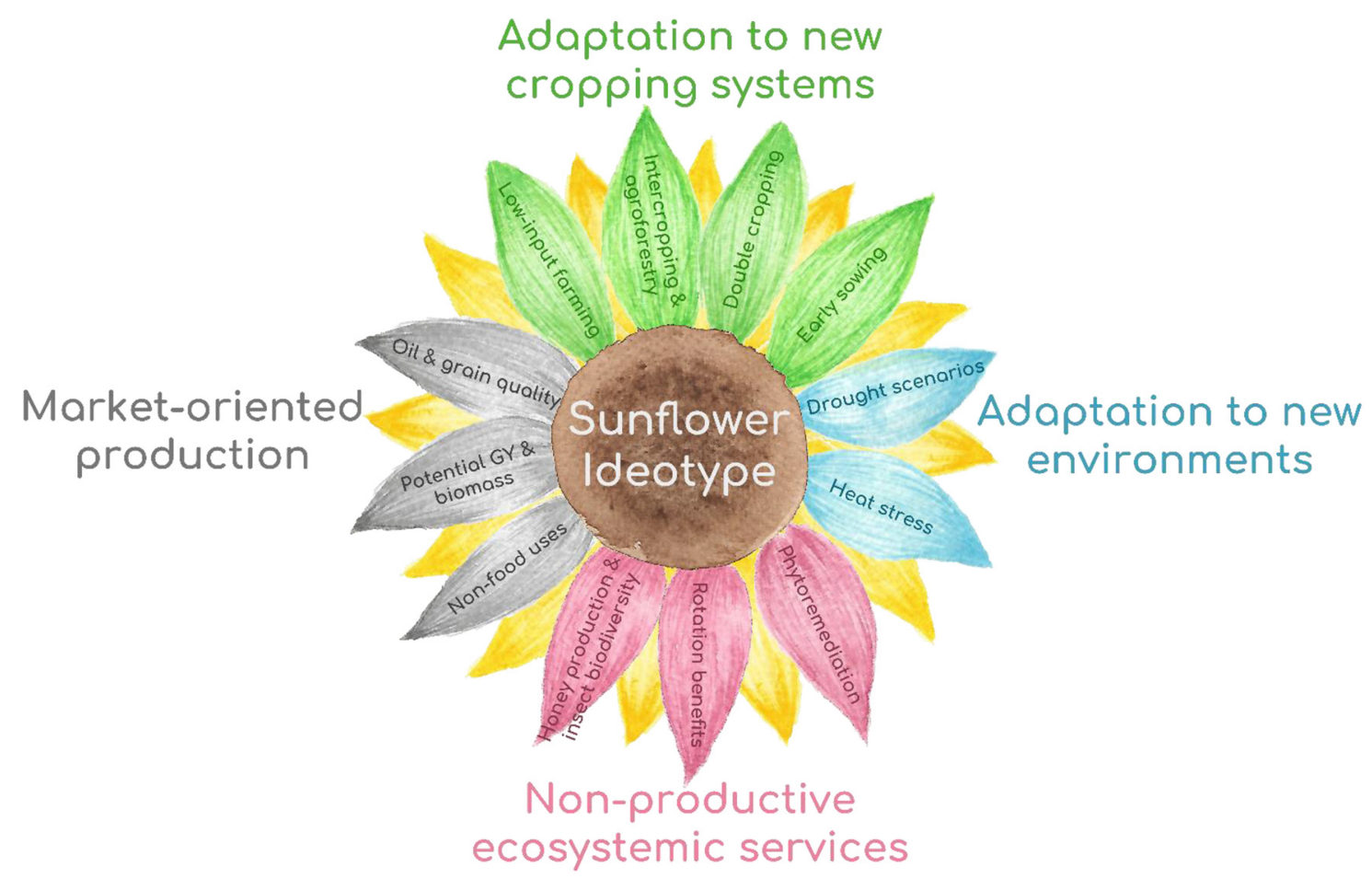

Fig. 1. Multicriteria design and evaluation of sunflower ideotypes.

varieties in delivering ecosystem services (Sects. 5 and 6). Finally, we will discuss new research approaches to identify and screen adapted traits and design ideotypes for specific climate, cropping management and ecosystemic needs (Sect. 7).

\section{Varietal adaptation to climate change}

\subsection{New climatic constraints for sunflower production}

Climate change $(\mathrm{CC})$ is characterized by higher temperatures, elevated atmospheric $\mathrm{CO}_{2}$ concentrations, extreme climatic hazards, reduced water availability in some regions, waterlogging in others (IPCC, 2014). With ongoing climate change, sunflower, as a spring-sown rainfed crop, could be more exposed to the direct effect of heat stress at anthesis or during grain filling and to different and unpredictable drought scenarios during its growing cycle, both factors resulting in severe yield losses, oil content decrease and alterations of fatty acid composition (Moriondo and Bindi, 2007; Moriondo et al., 2011; Donatelli et al., 2015; Andrianasolo et al., 2016). In the present and future climatic context, sunflower cropping offers a wide range of options for attenuating or preventing the negative impacts of climate change (Debaeke et al., 2017b; Awais et al., 2018). Adaptations through crop management (e.g. modifying sowing dates), breeding (earliness, stress tolerance) and shifting growing areas could be introduced, assessed and combined at field level to partly cope with CC negative impacts. At farm level, diversification of crop management systems (e.g. range of sowing dates and/or maturity groups) could be a way to adapt to more variable and unexpected weather conditions. Climate change could also offer some new opportunities with warmer winters and longer growing periods allowing sunflower to be cultivated as a double crop after a winter cereal or as a winter crop itself.

Current varieties could probably be part of the solution. But their potential in more constrained conditions will have to be explored by combining field networks with sufficient water deficits and platforms to mimics water constraints. Breeding will be necessary as well to reinforce some under-represented maturity groups (e.g. very early hybrids) and to develop hybrids more tolerant to drought and heat under higher $\mathrm{CO}_{2}$ (Miladinović et al., 2019; Attia et al., 2021).

\subsection{Early sowing (as an escape strategy)}

\subsubsection{Description of the practice}

By anticipating the timing of critical growth stages, the exposure of sunflower crop to the most stressful abiotic factors (heat and drought) can be minimized. Therefore, sowings in early spring (about 1 month earlier than the common practice, once soils have warmed up to $7-9{ }^{\circ} \mathrm{C}$ ) have been tested in temperate regions from Western and Southern Europe to escape the risk of high temperatures and water stress during flowering period (e.g. Alline et al., 2008). However, the risk of losing the plant stand increases as sowing date is anticipated because of cold or frost damage to seedlings and young plants but also because of greater exposure to predation by soil insects, slugs or birds and infection by soilborne diseases when emergence phase is too long. Additionally, difficult germination and weak plant establishment combined with slow development of plants could delay the canopy closure and favor the growth of weeds. Cold stress can impact dramatically the root system development with consequences on water and nutrient uptake later in the season. 
In some Mediterranean regions (e.g. South of Spain and Italy, Morocco) or in Asia (India, Pakistan) characterized by mild winters, sunflowers can even be planted in late autumn or winter with good results in water use efficiency and yield (Gimeno et al., 1989; Boujghagh, 1993; Gosset and Vear, 1995; Flagella et al., 2002; Barros et al., 2004; Tariq et al., 2018). With such very early sowings, more of the growing cycle takes place under low evaporative demand (and cooler conditions), so water productivity is higher, and high summer temperatures during flowering and grain filling are partly avoided (Soriano et al., 2004).

In addition, sunflower production area is often expanding to marginal regions with suboptimal growing conditions (e.g. southwestern Argentina). In Europe, the cultivation area of sunflower could move northward with climate change exposing the crop to more frequent low temperatures during the first part of the crop cycle (Debaeke et al., 2017b).

However, early sowing could be more than an escape strategy when combined with deep soils or supplemented by irrigation. Associated to late maturing cultivars, it could be an option to take advantage of the increasing heat units and $\mathrm{CO}_{2}$ with global warming (Donatelli et al., 2015). In this case, varieties should be tolerant to fungal diseases (e.g. phomopsis) as the risks might increase with early sowing (Debaeke et al., 2014).

Anticipating (or delaying) sowing dates will change incident radiation and thermal conditions during the critical periods for yield components and oil determination. This could change the grain number per unit area, the unit grain weight or the oil composition depending on the time and intensity of the constraints as was reported by Cantagallo et al. (2004), Izquierdo et al. (2008) and Echarte et al. (2010).

\subsubsection{Varietal traits for this new practice}

\subsubsection{Physiological aspects of cold tolerance (and response to low temperatures)}

Being able to sow early to maximize the growing season and escape drought and heat stress increases the importance of cold tolerance among varieties, especially during the vegetative period. In spite of global warming, climatic accidents are not excluded in early spring, and a low and fluctuating temperature regime (including several small frost events) is expected. Consequently, seedlings and young plants could be exposed to cold stress (low temperatures, frost) in the early stages of development (germination, emergence, 2-3 leaf stage). Cold stress, which includes both chilling $\left(T>0{ }^{\circ} \mathrm{C}\right)$ and freezing $\left(T<0^{\circ} \mathrm{C}\right)$, modifies gene expres-sion and plant metabolism with consequences on many biological functions (Alline et al., 2010; Janmohammadi et al., 2015; Hniličková et al., 2017). The conditions of exposure (timing, intensity, duration) are to be considered to explain the final response. Cold conditions may affect duration and rate of emergence, plant survival and early growth.

\subsection{Base temperature for germination}

Base temperatures for germination $(\mathrm{Tb})$ between 3.0 and $6.9^{\circ} \mathrm{C}$ have been reported in sunflower with intra-specific variability (Connor and Hall, 1997; Khalifa et al., 2000; Trudgill et al., 2000). González-Belo et al. (2014) observed Tb values between 0.7 and $3.3^{\circ} \mathrm{C}$ among 9 genotypes, the highlinoleic genotypes germinating earlier at low temperatures.

\subsection{Frost damage (freezing stress)}

During early growth stages, sunflower plants can withstand temperatures in the -3.3 to $-3.8^{\circ} \mathrm{C}$ range for short periods (source: NSA of Canada). As the plants develop through the vegetative stages (V2 to V6) (Schneiter and Miller, 1981), they become progressively more sensitive to frost. At the V2 stage, the lowest temperature plants can withstand is -2.7 to $-3.3^{\circ} \mathrm{C}$ but, for the V4-V6 stages, -1.6 to $-2.2{ }^{\circ} \mathrm{C}$ is the lower limit. Alline et al. (2009) confirmed this information: at cotyledon stage, sunflower could resist to temperatures of -5 to $-7^{\circ} \mathrm{C}$ but as soon as the first leaves appear, $-3{ }^{\circ} \mathrm{C}$ could provoke severe necrosis on young plants. Cool temperatures $(0.5$ to $1.1^{\circ} \mathrm{C}$ ) over several days, coupled with wet soils and dew, help reduce frost damage but this process of hardiness is still poorly understood in sunflower (Hewezi et al., 2006). Most damage can be expected if temperatures change rapidly between extremes. Frost damage can result in partial destruction of the terminal bud with a loss of apical dominance causing branching from axillary buds and multiple heads later in the season, affecting greatly yield and quality (Boujghagh, 1993). Hniličková et al. (2017) identified some physiological mechanisms of resistance and tolerance of young sunflower plants to overnight freezing temperatures.

\subsection{Low temperature stress (chilling stress)}

Each plant species, more particularly each genotype, has an optimum range of temperatures for its normal growth and development. These cardinal temperatures depend also on the growth and development stage for a given genotype. When temperature moves beyond this optimal range, temperature stress affects leaf development and photosynthesis and this can be modeled by SUNFLO (Casadebaig et al., 2011). This approach allowed to estimate the grain yield loss due to chilling stress between 3 and $10 \%$ in a French multienvironment trial network (Mangin et al., 2017). Early sowing (or sowing in marginal regions) increases the occurrence and duration of sub-optimal temperatures during vegetative stages.

\subsubsection{Genetic variability and breeding}

Breeding for cold tolerant genotypes should contribute to stabilizing sunflower cultivation in areas frequently exposed to early spring frosts and night chilling. Two directions have been explored (Vear, 2016): germination at low temperatures and plant resistance to frost, either by withstanding cold periods without developmental damages, or by the capacity to recover later without impacts on production. These different tolerance strategies still need to be characterized in the current varieties and the other genetic resources to ensure efficient optimization of $\mathrm{G} \times \mathrm{E} \times \mathrm{M}$ interactions.

Cold resistance should be improved in the early stages of growth and development, in order to enable successful plant establishment. Although less often evoked, cold resistance at maturation could enable sunflower growing at higher altitudes and in colder regions (Škorić, 2009).

Varieties with lower base temperatures, shorter thermal times for emergence and increased vigor should be targeted in early sowings (Houmanat et al., 2016). For instance, such varieties adapted to autumn sowings have been selected in Morocco (cv. Ichraq - Nabloussi et al., 2008) and improved germplasm has been evaluated (Houmanat et al., 2016). 
Chlorophyll content and specific leaf area among others have been genetically associated with cold tolerance, so they could be used as selection criteria in breeding programs (Alline et al., 2009, 2010; Fabio et al., 2016). From QTL analyses, it was illustrated that several putative genomic regions are involved in the variation of physiological traits under cold conditions (Alline et al., 2009; Škorić, 2009; Tetreault et al., 2016; Mangin et al., 2017; Miladinović et al., 2019).

Conventional breeding methods have moderately succeeded in improving the cold tolerance of major crop plants (Škorić, 2009; Sanghera et al., 2011; Miladinović et al., 2019). Therefore, wild populations of sunflower (e.g. H. maximiliani) growing in US mountains with harsh winters and cold springs could be a source of variability for improving the cold tolerance of H. annuus (Tetreault et al., 2016; Seiler et al., 2017). In Argentina, Gutierrez et al. (2016) pointed out that $H$. petiolaris could also be a useful genetic resource to explore.

Mangin et al. (2017) identified 9 genomic regions associated with oil yield plasticity in response to chilling stress in a core collection of cultivated and wild accessions. This genetic material together with the molecular markers constitute a valuable resource to improve this trait and decipher the physiological processes of importance for sunflower to tolerate cool nights. Hernandez et al. (2020) observed a wide genetic variation for the tolerance to freezing in the primary gene pool of sunflower and suggested that tolerance might be introgressed into elite germplasm without growth penalties.

Based on general physiological understanding of plant development and cropping issues in cold conditions, we can hypothesize that particular attention to vigor, root development and resistance to soilborne diseases such as downy mildew should be considered when ideotyping sunflower genotypes adapted to early sowing.

\subsection{Moving to new environments}

Moving to more favorable environments is a way to escape unsuitable conditions and exploit emerging opportunities for crop growing. New cultivation opportunities could be expected in northern parts of Europe, North America, Ukraine or Russia where sunflower is not grown presently and where it could usefully contribute to diversify cereal-based cropping systems (Tuck et al., 2006; Deppermann et al., 2018). This will require early maturing, cold-tolerant varieties with a low susceptibility to sclerotinia head rot, as this disease is more present in cool and wet environments. In the US, northward expansion of sunflower was limited by the lack of commercial hybrids with such early maturity. Hulke and May (2018) recently provided early-maturing restorer inbred germplasms with high yield potential. In Europe, new hybrids have been recently registered for northern conditions but their spread is still constrained by the limited use of these very early varieties in current cropping systems.

\subsection{Double cropping}

\subsubsection{Description of the practice}

Due to its short growing season together with the global warming context, sunflower becomes an attractive option for double cropping following the early harvest of winter crops (Salera, 1992; Lecomte, 2009; Gesch and Archer, 2013).
Numerous results have been reported from North and South America, France, Italy, Serbia, India, Iran and Turkey (Sojka et al., 1989; Dragovic et al., 1992; Salera, 1992; Bahrani et al., 2009; Ada and Tamkoç, 2015; Akcay and Dagdelen, 2016; Ross, 2016). The practice however requires short-season cultivars, associated to minimum tillage and sowing soon after harvest, and sufficient irrigation for good establishment and minimization of climatic risks (cold, heavy rain) at the end of the season. Among cultivars adapted to second crop ( $<100$ days), Dalchiavon et al. (2016) in Brazil obtained the highest yields with the latest and tallest varieties among a collection of hybrids. Double cropping is also used for energy (e.g. in Germany, Graß et al., 2013) or silage (e.g. in USA, Sheaffer et al., 1977; in Brazil, Tomich et al., 2003) with different varietal objectives. In the US, double crop sunflower can be used as an emergency crop or when the season is too short to produce mature corn for silage.

\subsubsection{Varietal traits for this new practice}

Very early-maturing sunflowers are required for double cropping, growing degree days (GDD) ranging from 1300 to $1400^{\circ} \mathrm{C}$.days $\left(\mathrm{Tb}=6^{\circ} \mathrm{C}\right)$. In Europe, these hybrids often come for the selection of very early materials intended for main sunflower cropping in the northern regions. Among these cultivars, 100-120 days varieties are adapted to sunflower cropping in the continental parts of eastern and central Europe. The reproductive period (from anthesis to physiological maturity) of such late-sown cultivars is proportionally longer than in conventional hybrids. They could be unadapted to late sowing and climatic conditions of southern Europe where hot and dry conditions are prevailing in summer. Indeed, delaying sowing date in early summer will change dramatically the radiative, water and thermal conditions during the most critical periods of yield determination. However, trials where cultivars are tested for their response to late sowing under double cropping conditions are not widespread and should be encouraged.

In France, for instance, hybrids less susceptible to sclerotinia head rot should be preferred because of irrigation around flowering and possible wet and cold conditions during ripening (Lecomte, 2009). Because of high temperature and low relative air humidity, fungal diseases as phomopsis should be less frequent in relation with a shorter vegetative period and lower leaf area index (LAI). Oleic cultivars are not recommended because of possible low night temperatures during grain filling which can reduce the biosynthesis of this fatty acid (Izquierdo et al., 2002).

Double cropping, sowing in cool environments or northern regions, and escaping summer drought by early sowing all require early-flowering and/or early-maturing hybrids. As for many crops, flowering time is a quantitative trait, which has been crucial for the domestication and spread of sunflowers into new ecoclimatic regions (Blackman et al., 2011). In breeding programs, flowering date (expressed as number of days from sowing or emergence) and seed moisture at harvest are the two characters regularly measured (Tab. 1) and used as indicators of earliness, in order to assign a genotype to a maturity group, and to discard very late-maturing materials (Vear, 2016). Generally, early-maturing hybrids are characterized by the shortening of the period from star bud to early anthesis growth stages resulting in lower LAI, total 
evapotranspiration, and yield potential than later hybrids (Chervet and Vear, 1990; Fick and Miller, 1997).

Genetic and environmental controls of flowering in sunflower are complex and mostly undefined. Photoperiod and temperature are the primary environmental factors regulating the transition to flowering in sunflower (Goyne et al., 1989). Three classes of photoperiod response (day neutrality, short-day response, and long-day response) were observed in H. annuus (Wien, 2008; Blackman et al., 2011). QTLs and/or mutations involved in the control of flowering time in the cultivated sunflower were identified (Leon et al., 2000, 2001; Cadic et al., 2013) and the genetic network controlling flowering time including 475 genes could be reconstructed based on similarity to $A$. thaliana (Badouin et al., 2017). Recently, Todesco et al. (2020) identified major haplotypic variations in wild Helianthus species (H. annuus, $H$. petiolaris and H. argophyllus) driving flowering time. Such haploblocks are present in cultivated hybrids and certainly impact the capacity to introduce favorable alleles in their vicinity due to modified recombination rates.

\subsection{Breeding for drought-resistant and/or water use efficient genotypes}

\subsubsection{Description of the practice}

When compared to other field crops, sunflower has moderate water requirements, can tolerate short-term drought and partly recovers from water stress (García-Vila et al., 2012). Reducing water consumption results in moderate yield reduction $(\mathrm{Ky}<1)$ because sunflower forms a deep root system, extracts water from the deeper soil layers and can efficiently regulate water transpiration from leaves when submitted to water deficit. However, long-term water deficits can severely affect grain yield, oil content and quality, and other important yield traits (Ahmad et al., 2014; Hussain et al., 2018; Debaeke and Izquierdo, 2021). Although water shortage affects all phenological phases, the maximum yield reduction is observed when drought occurs during the reproductive phase (García-Vila et al., 2012). Therefore, irrigation around flowering stage is advised to maximize yield response (Goksoy et al., 2004; Champolivier et al., 2011).

In the near future, sunflower could be increasingly exposed to water deficit due to higher evapotranspiration and less effective rainfall with global warming (García-Vila et al., 2012; IPCC, 2014; Donatelli et al., 2015; Debaeke et al., 2017b; Awais et al., 2018). Therefore, it is essential to identify the physiological, molecular and genetic components of sunflower tolerance and resilience to water stress in this emerging context (Hussain et al., 2018; Miladinović et al., 2019).

In water-limited environments, the optimal crop management must ensure a rapid canopy closure, avoid excessive LAI at anthesis, maintain a green canopy throughout the grain filling period while fully deplete the root zone to exhaust the soil reservoir at maturity (Fereres et al., 1986; Merrien and Grandin, 1990; García-Vila et al., 2012; Lisanti et al., 2013). Management decisions, through choice of cultivars (characterized by phenology, potential leaf area, response of leaf expansion and transpiration to water deficit) and optimal sowing dates, are crucial in this context as they will play on the environmental patterns of water supply and demand (Casadebaig and Debaeke, 2011; Casadebaig et al., 2016). Shifting the cropping season to less evaporative periods may reduce the crop exposure to drought (Soriano et al., 2004), while the choice of early maturing cultivars may increase the fraction of water used after anthesis leading to greater harvest index and yield (Sadras and Connor, 1991). Crop population density adjusted to the maturity group ensures an adequate exploitation of available water resources while preventing excessive and inefficient crop transpiration (Villalobos et al., 1994). In addition, N-fertilization practices (rates, splitting) adapted to available water for irrigation will maximize input efficiency (García-López et al., 2016).

\subsubsection{Varietal traits for this new practice}

Drought tolerance in breeding programs could be achieved following two main directions: (i) stress avoidance which includes reduced transpiration and water conservation and (ii) increased water uptake from the soil by optimizing root architecture and functioning. We previously indicated the importance of drought escape strategies (cf. Sects. 3.2-3.4).

\subsubsection{Stress avoidance}

When subjected to soil drying, sunflower plants immediately adapt their transpiration by two reversible physiological processes (Connor and Hall, 1997; Debaeke and Izquierdo, 2021): (i) leaf wilting, which saves soil water and protects leaves from thermal stress and high radiation loads (Velázquez et al., 2012) and (ii) stomatal closure, which increases the resistance to gaseous loss and saves water for the plant (Hernández and Orioli, 1985; Gimenez and Fereres, 1986; Kiani et al., 2007). After anthesis, the most efficient adaptation is provided by stomatal closure (Connor and Jones, 1985; Maury et al., 1996). Leaf senescence may be hastened also but with less impact on plant transpiration as it affects in priority basal leaves, which are less active and smaller (Sadras et al., 2000). Leaf wilting can be observed before and after anthesis (Guiducci, 1988). After anthesis, due to complex interactions between leaf senescence, wilting, and reduced stomatal conductance, it is difficult to identify a predominant factor of adaptation to water deficit (Connor and Hall, 1997). In contrast, before anthesis, the main adaptation strategy to maintain plant water status is to reduce leaf size with delayed consequences on both radiation interception and evaporative demand (Takami et al., 1981; Connor and Jones, 1985; Cox and Jolliff, 1986; Guiducci, 1988; Sadras et al., 1991).

The possible large genotypic variability in leaf expansion and stomatal closure responses to water deficits has not been extensively explored in sunflower. Pereyra-Irujo et al. (2008) reported genetic variability for the response of leaf growth to water deficit among 18 inbred lines. Casadebaig et al. (2008) compared these responses for 25 hybrids subjected to a progressive soil dry-out in greenhouse. No impact was observed on leaf expansion until the fraction of transpirable soil water (FTSW) in the root zone declined below 0.6 , but it had to decline below 0.4 to induce stomatal closure. Two contrasted adaptive strategies were observed among genotypes, either conservative (decreasing water loss) or productive (maintaining water uptake). Conservative genotypes have a 
gradual response to water deficit (stomatal closure for low soil water deficit) and might be most suited to environments with severe water deficits where survival is the priority. However, this strategy may not be the most efficient for environments with short, frequent and moderate soil water deficits alternating with well-watered periods. In such conditions, a steeper response ("productive" strategy), maintaining organ expansion, photosynthesis and biomass production, could result in better yield maintenance in such conditions (Casadebaig and Debaeke, 2011).

Water uptake maintenance is facilitated within plant cells by osmotic adjustment (OA), a biochemical mechanism that helps plants to acclimatize to dry conditions. A large intraspecific variability in OA was observed for sunflower (Chimenti and Hall, 1993), the genotypes with a high capacity for OA having also leaf expansion less reduced by drought (Chimenti and Hall, 1994). Chimenti et al. (2002) observed that genotypes with high OA could extract twice as much water from the soil during a drought period occurring between V11 and R5.5.

To screen and develop sunflower hybrids better adapted to water stress, several indicators at field level and protocols in dedicated platforms should be associated (e.g. plant and leaf growth, senescence, transpiration, OA potential, leaf temperature...) (Vannozi et al., 1999; Pereyra-Irujo et al., 2007; Rauf, 2008; Gosseau et al., 2019).

Obviously, cultivated sunflower has a narrow genetic base and is deficient in drought-survival mechanisms which were lost during the selection process towards high yields. However potential sources of drought resistance were identified in wild sunflower relatives such as $H$. anomalus and $H$. deserticola, native to drought-prone environments (Kantar et al., 2015; Seiler et al., 2017). Up to now, H. argophyllus was the most often used species for such purpose, as it can be easily crossed with cultivated H. annuus (Hussain et al., 2019).

\subsubsection{Root system and water capture}

As compared with other crops, sunflower is known to have a well-developed and deeply penetrating root system which is capable of fully depleting the water (and nutrients) present in subsoil layers. This was extensively reported by comparative field studies (Bremner et al., 1986; Cox and Jolliff, 1987; Hattendorf et al., 1988; Rachidi et al., 1993; Dardanelli et al., 1997; Cabelguenne and Debaeke, 1998; Stone et al., 2001; Merrill et al., 2002). Sunflower's root system is "explorative" of large soil volumes with a combination of thick and thin roots, small average specific root length, and small root length density, which explains why sunflower can extract more water than most other crops, especially from deep soil layers (Connor and Hall, 1997). However, in undisturbed soils with hard layers in depth or compacted in sub-surface, the potential of deep rooting of sunflower could be dramatically reduced with consequences on plant height and growth (Scapinelli et al., 2016).

Some variations in root depth were observed among sunflower genotypes in relation with plant height and maturity group, long-season and tall varieties exploring deeper the soil layers and extracting water from drying soil more efficiently (Gimenez and Fereres, 1986; Angadi and Entz, 2002; Radanielson et al., 2012). Genotypes with longer roots can also explore deeper soil layers and hence exhibit higher level of tolerance to drought stress conditions (Angadi and Entz, 2002). When applying water deficit, Rauf et al. (2009) observed longer root length for drought tolerant inbred lines (and a reduced length for susceptible ones) and higher values of rootto-shoot ratio in almost all genotypes regardless of their drought tolerance. Pre-anthesis drought also increases the proportion of roots in depth mainly by reducing the amount in the uppermost layers (Connor and Jones, 1985).

The development of more productive and drought-tolerant lines in breeding programs requires the knowledge of root traits and functions and their effect on productivity (Miladinović et al., 2019). Traits such as root length and diameter, root length density, root volume, fresh and dry root weight, and total dry matter were recognized as significant indicators of drought tolerance (Rauf, 2008; Nagarathna et al., 2012; Comas et al., 2013). However, in spite of previous studies, very few explorations of the genetic variation in root traits have been published in sunflower. Phenotyping root traits is extremely difficult at field level, because the root system of field-grown plants is impossible to extract completely (Nagarathna et al., 2012). The architecture of the root system can be studied during the very early stages in controlled conditions providing relevant information (Aguirrezábal and Tardieu, 1996). Masalia et al. (2018) revealed in growth room a substantial variation for seedling root morphology and growth traits among 288 lines, resulting in no tradeoffs between aboveground and belowground biomass which is promising for the selection of deep-rooting genotypes.

A wide range of genetic variation for root morphology was described by Seiler (1994) among annual Helianthus species. An increased percentage of deep roots in response to water deficits was found with H.petiolaris (Sobrado and Turner, 1986). As for shoot traits, these desirable traits from wild species could be introgressed into cultivated sunflower by interspecific hybridization process resulting in substantial genetic variability in root growth (Seiler, 2008).

\subsubsection{Water-use efficiency}

Water-use efficiency (WUE) is the ratio of total carbon in the plant and the total loss of water due to transpiration (Blum, 2005). Creating high-WUE genotypes is often the most efficient and cheapest strategy to deal with the problem of water deficit (Rauf, 2008). Selecting for high harvest index will most likely result in genotypes with high WUE. Differences in WUE were observed among sets of hybrids or inbred lines (Lambrides et al., 2004; Adiredjo et al., 2014; Canavar et al., 2014). These authors suggested that leaf carbon isotope discrimination could be an indirect tool for breeding for WUE in sunflower. Strong negative correlations were observed between whole plant WUE (or intrinsic WUE) and leaf carbon isotope discrimination with decreasing water availability.

\subsection{Breeding for heat tolerance}

In spite of early sowing, climate change will expose more and more sunflower crop to high temperatures during the reproductive phase (Moriondo et al., 2011) with dramatic consequences for pollination, fertilization, seed set, rate and duration of seed growth, seed weight and oil characteristics (Connor and Hall, 1997; Chimenti and Hall, 2001; Chimenti et al., 2001; Astiz and 
Hernandez, 2013; Andrianasolo et al., 2016). The temperature of $35^{\circ} \mathrm{C}$ was mentioned as a stressful threshold for sunflower at least during early- to mid-grain filling (Rondanini et al., 2003, 2006). According to Terzic et al. (2017), temperatures above $27^{\circ} \mathrm{C}$ reduce nectar production, while those above $33^{\circ} \mathrm{C}$ completely stop it. Chabert et al. (2020) observed that nectar sugar mass per floret increased with air temperature over the range of $16-32^{\circ} \mathrm{C}$ and appeared to decrease beyond $32^{\circ} \mathrm{C}$ on the overall range of cultivars sampled.

Avoiding adverse conditions (Sect. 3.2) or breeding varieties with increased resistance to heat shocks are two complementary adaptive strategies. Higher air temperature can negatively affect sunflower growth by inducing shorter phenological phases. Resulting shorter crop duration could be compensated for by sowing early long-cycle cultivars (Debaeke et al., 2017b). The increased temperatures could also lead to rapid senescence and diminish oxidative protection in sunflower primary leaves (de la Haba et al., 2014). Fortunately, increasing transpiration should keep the leaves relatively cool if enough water is supplied by a deep and well-developed root system (cf. Sect. 3.5).

Other traits related to plant architecture could be efficient to avoid heat stress. For instance, the orientation of the capitulum could be optimized. Ploschuk and Hall (1995) found that restraining a capitulum in a vertical position increases temperature by $10^{\circ} \mathrm{C}$ during a sunny day and reduces the duration of grain filling by $2-6$ days. Through modelling, Guilioni and Lhomme (2006) found that plants around $2 \mathrm{~m}$ high, with small LAI and a capitulum inclination between $45^{\circ}$ and $90^{\circ}$, should experience lower temperatures. In addition, Kalyar et al. (2013) demonstrated that a genotype with upward inclined leaves was superior to that with downward inclined leaves as it maintained lower post-noon temperature and heat injury. Leaf temperature adjustment over time was proposed as a useful trait for selecting heat-tolerant genotypes. In addition, root type, head position, tolerance to high atmospheric demand for water vapor, increased capacity of a plant to produce more pollen, high seed filling rate, and rapid synthesis of oil under hot conditions were suggested as important criteria for selecting accessions tolerant to high temperatures (Miladinović et al., 2019).

A wide genetic variation for the tolerance to heat exists in the primary gene pool of sunflower (Hernandez et al., 2020). These authors found no evidence of a growth-tolerance tradeoff. Regarding germplasm, $H$. argophyllus was suggested as a useful source of heat tolerance traits due to its silver leaves that reflect sunbeams and reduce transpiration (Warburton et al., 2017). In addition, Seiler (2012) recommended several wild relatives as $H$. anomalus Blake, $H$. deserticola, $H$. nuttallii, and $H$. petiolaris as possible germplasms for heat stress studies.

\section{Adaptation of variety offer for production in agroecological cropping systems}

\subsection{New context for crop production}

Agroecological cropping systems in the wider sense (incl. organic farming) are characterized by the application of a limited amount of exogenous inputs (agrochemicals, fertilizers), the actions of which are partly compensated by the intensification of ecological processes (through cover crops, diversified rotations, legumes...) (Duru et al., 2015). Such systems could rely on intercropping and agroforestry which associates several species with different outcomes and functions. Soil tillage can be drastically reduced especially when considering conservation agriculture which combines reduced tillage, crop rotations and more or less permanent soil covering (Govaerts et al., 2009). In such systems, varieties must be more resistant to biotic factors and have to capture more efficiently resources (water, nutrients, light) at soil and canopy level.

\subsection{Low-input management and organic farming}

\subsubsection{Description of the practice}

As a cash crop, sunflower is mostly grown for grain production in low-input (rainfed) cropping systems where it brings some yield stability (Debaeke et al., 1998; Silvestri et al., 2000; Mazzoncini et al., 2006). Sunflower may be attractive to organic grain crop farmers, who often rely on diversified crop rotations to manage insect pests and fungal diseases (Mohler and Johnson, 2009). Grain yield of organically-grown sunflower was lower by $41 \%, 17 \%$ and $44 \%$ in 2002, 2003 and 2004 respectively when compared to the conventional practice in Italy (Mazzoncini et al., 2006). In a 5-year survey in France, average organic yield may reach up to $82 \%$ of conventional one (Le Gall and Lecomte, 2019). Mechanical weed control being feasible as row widths are greater than $50 \mathrm{~cm}$, inter-row tillage is practised in more than $40 \%$ of the fields in France. However, in such low-input systems, nutrient stresses, weed infestation and disease attacks may limit grain yield and possibly oil concentration but the literature on management practices for organic and low-input sunflower production is extremely limited.

\subsubsection{Weed management}

Ineffective weed suppression is one major reason of lower yields in organic cropping systems (Ryan et al., 2009; Seufert et al., 2012). Weeds that emerge and establish during sunflower germination can compete with the crop and reduce sunflower yield. Sunflower seed yield is maximized when the crop is kept weed-free for 4-6 weeks after sowing (Johnson, 1971). Cultivating with a tine weeder in the two weeks after sowing has been shown to control weeds as effectively as herbicides, but cultivating can also reduce sunflower plant density. Previous research has shown that high seeding rates can facilitate weed suppression in organic sunflower (Mouillon et al., 2020). However, high sunflower density can also lead to disease attacks such as white mold and phomopsis stem canker (Debaeke et al., 2014), as well as crop lodging which can reduce seed harvestability. In order to limit weed emergence in the early stages, organic farmers often decide to plant later than conventional ones in order to have time for a false sowing and thus mechanically control the first flush of weed emergence before sunflower planting (Le Gall and Lecomte, 2019).

\subsubsection{Nutrient stress}

$\mathrm{N}$ deficiency is often mentioned as a limiting factor in organic farming (Stockdale et al., 2001). In spite of the moderate $\mathrm{N}$ rate applied to sunflower in conventional systems, 
and the use of legumes in the rotation, crop growth could be limited by $\mathrm{N}$ deficiency during the vegetative phase with direct consequences on radiation interception and photosynthesis. At the same time, this could reduce pre-anthesis leaf development and evapotranspiration which could be favorable for preserving water during grain filling in drought-prone environments (Sadras and Connor, 1991).

\subsubsection{Disease attacks}

As fungicides are not widely used in sunflower, the use of tolerant varieties combined to less favorable microclimate for the infection of plants by fungi (due to lower nitrogen nutrition index and lower LAI) should not increase much the risk of diseases (e.g. phomopsis, phoma, sclerotinia) in sunflower as compared to conventional systems (Debaeke et al., 2014).

\subsubsection{Varietal traits for this new practice}

Currently, there is no strong difference between the characteristics desired for organic and conventional production systems, and yields are often well correlated between the two systems. Contrary to wheat, there is no specific network to assess the performance of sunflower varieties in organic farming. Generally, varieties used in organic farming are rather old and less diverse than in conventional systems (Le Gall and Lecomte, 2019).

\subsubsection{Competitiveness against weeds}

Weeds compete with sunflower for moisture, nutrients, and depending on species for light and space. Weed competition cause substantial yield losses in sunflower, with reports ranging from 20 to $70 \%$ (Zimdahl, 2004). Weeds are usually a problem because sunflower does not cover ground rapidly enough to prevent them from becoming established. The critical period of weed competition was found to occur from 25 to 43 days after sowing (Wanjari et al., 2000). However, once well established, sunflower is a good competitor with weeds due to its shoot height, extinction coefficient between 0.8 and 0.9 and deep rooting system (Onofri and Tei, 1994). In spite of the use of mechanical weeding (which doesn't guarantee a complete weed control on the row), competitiveness against weeds will be important to consider in such low-input systems.

Using cultivars with high competitive ability against weeds is one of the effective strategies for sustainable weed management which has been explored in other major crops (e.g. cereals).

Zarch et al. (2017) showed that rapid emergence and plant height increasing rate at first 53 days after sowing and leaf area development rate between 17 to 53 days after sowing were the most important effective factors that increase sunflower competitiveness against Amaranthus albus. They observed a significant difference between the 6 cultivars under study for Competitive Index. Latify et al. (2017) suggested that combining highly competitive cultivars with proper living mulch species would be a feasible weed management that should be modulated by the dominant weed spectrum.

Emergence rate, rapid root growth, seed vigor, development rate of leaves, rapid root and shoot biomass accumulation, rapid canopy closure and plant height are important traits in relation to the competitive ability between different cultivars of crops. These characters have been seldom evaluated among sunflower cultivars.

\subsubsection{Increasing nutrient uptake and use efficiencies}

Varieties highly tolerant to suboptimal levels of nutrients $(\mathrm{N}, \mathrm{P}, \mathrm{K})$ or efficiently using limited resources from the soil or the fertilizers are welcome in low input crop management systems.

In breeding programs, the following plant properties should be taken into account: (a) the ability to produce nearmaximum yields on low-level soil nutrients and (b) the root system that efficiently uses large amounts of soil nutrients, in order to create varieties with high NUE, PUE, or KUE that can contribute positively to environment (Clark and Duncan, 1991; Miladinović et al., 2019).

At least three ratios could be calculated to compare the different genotypes regarding nutrient capture and utilization efficiencies (Dalla Costa and Giovanardi, 1996): the apparent $\mathrm{N}$ recovery (ANR: plant $\mathrm{N}$ uptake/ $\mathrm{N}$ fertilizer applied); the physiological $\mathrm{N}$ efficiency (PE: grain yield/plant $\mathrm{N}$ uptake) and the agronomic efficiency (AE: increase in grain yield of the fertilized crop compared to the unfertilized crop per unit of $\mathrm{N}$ fertilizer applied). Sunflower has lower PE and decreased ANR at high $\mathrm{N}$ fertilizer rates than maize, resulting in an overall lower AE.

Most of the studies were concerned by NUE ignoring the other nutrients but very few studies compared the previous ratios for a wide range of inbred lines or hybrids by contrast with other highly-fertilized crops (e.g. wheat, maize, oilseed rape). ANR, PE or AE were not identified as priorities for breeding in sunflower. However, Montemurro and De Giorgio (2005) observed differences in NUE for 2 cultivars at field level and recently Keipp et al. (2019) in a pot experiment obtained significant differences for the three nutrient-utilization efficiencies (NUE, PUE, and KUE) among 25 sunflower hybrids.

The potential for the creation of varieties with superior nutrient-utilization efficiencies depends largely on: (i) the genetic variability in the species present for that particular NUE (or PUE or KUE)-regulated property and (ii) the development of a methodology for the precise quantification of physiological parameters reflecting an effective NUE, PUE or KUE (Baligar et al., 2001; Miladinović et al., 2019). In sunflower, the evaluation of nutrient uptake in grain and vegetative parts requires heavy sampling at field level and thus is relatively inaccurate for discriminating small differences among genotypes. Dense root system is probably a favorable trait in sunflower for capturing most efficiently $\mathrm{P}$ and $\mathrm{K}$, two nutrients with a low mobility in soils (Fernandez and Rubio, 2015).

\subsubsection{Breeding for disease resistance}

Sunflower diseases causing the highest damages worldwide are Sclerotinia head rot and stalk rot, Phomopsis stem canker, rust, and downy mildew (Markell et al., 2015). Breeding for fungal disease resistance or tolerance is a continuous and renewed challenge in sunflower both in conventional and low-input systems because of the reduction 
of fungicide applications, the absence of satisfactory chemical or cultural control methods exist for some potentially yieldreducing fungal diseases and the regular emergence of new pathotypes which threaten the efficacy of efficient genetic control (Vear, 2016; Miladinović et al., 2019).

Increasing durable genetic tolerance or resistance to the dominant fungal diseases is one of the basic tasks of sunflower breeders, in a double context of more ecological production and changing climate. Currently genetic resistance exists to diseases such as P. halstedii and Verticillium, high level of tolerance has been selected for Phomopsis, satisfactory tolerance exists for Phoma macdonaldii and Sclerotinia sclerotiorum, and partial disease tolerance exists against Botrytis cinerea (Vear, 2016). Resistant varieties should be optimally used to maintain the resistance sustainability and multiresistant varieties should be encouraged to face the diversity of pathogens.

Variety mixture is often recommended in cereals in order to reduce the use of fungicides and increase crop resilience (Barot et al., 2017). In sunflower, this practice has not been reported in the literature and only empirical approaches have been tested (Debaeke et al., 2017a). However, Tourvieille de Labrouhe et al. (2010) mixed different major resistance genes (Pl) to downy mildew using multi-hybrids during 5 years of continuous cropping. This obviously contributed to a more durable control of downy mildew by delaying the appearance of new races.

\subsection{Intercropping}

\subsubsection{Description of the practice}

Sunflower was reported as a serious candidate for strip, row and relay intercropping systems (Robinson, 1984). Its desirable agronomic characteristics such as erect growth habit, harvestable head, relative resistance to lodging and drought, and minimal land cover makes sunflower an excellent component to intercrop with a short stature and/or duration crop.

The sunflower-soybean intercrop has emerged as a popular option that increases land productivity in the southern Pampas of Argentina, compared with sole crops, because of complementary use of resources between species (Echarte et al., 2011; Andrade et al., 2012; de la Fuente et al., 2014). More results were given for West Africa (Olowe and Adebimpe, 2009) for different varieties of sunflower and soybean. In France, this system is only profitable in very lowinput systems where sunflower growth is reduced and benefits from the soybean complementarity for $\mathrm{N}$ (Landé et al., 2012; Tribouillois et al., 2012).

In the tropics, sunflower can be intercropped with a wide range of crops (groundnut, maize, mungbean, sesame, cowpea...) (e.g. Olowe and Adeyemo, 2009). In the US, vegetable legumes (vetch, clover, alfalfa, medic, lentil...) were intercropped with sunflower with the objective of increasing soil cover, reducing soil erosion and adding nitrogen and organic matter to the soil (Kandel et al., 1997). Sunflower yield was reduced by $15 \%$ when it was sown at the same time than the legumes.

\subsubsection{Varietal traits for this new practice}

The optimal variety type for successful intercropping has not been extensively examined, as this system is not widespread. Kandel et al. (1997) did not observe significant yields for two contrasted hybrids (standard-height and - maturity hybrid vs early-maturing dwarf hybrid) intercropped with legumes. In Nigeria, Olowe and Adeyemo (2009) and Olowe and Adebimpe (2009) comparing the performance of 3 open pollinated sunflower varieties intercropped with sesame and soybean respectively, observed significant differences among the tested varieties relatively to the sole crops. From these limited experiences, it is impossible to indicate which varietal traits should be selected in priority for maximizing the performance of sunflower grown in intercropping.

\subsection{Reduced tillage}

Ploughing is still widely used as primary tillage (60\% in 2017 in France, Le Gall and Lecomte, 2019) because sunflower needs uncompacted soils for the establishment of its tap root system (Scapinelli et al., 2016). The situation is quite different in Argentina where about $80 \%$ of the sown area is conducted under no-tillage system for economic and agronomic reasons (Rodriguez and Brihet, 2019).

Several studies were conducted to evaluate the relative performance of sunflower under conventional and reduced tillage as main or double crop (Murillo et al., 1998; Halvorson et al., 1999; Lopez-Bellido et al., 2002; Bahrani et al., 2009; Seddaiu et al., 2016). Minimum or reduced tillage often appeared to be a more suitable strategy for rainfed agriculture in areas with frequent periods of scarce rainfall where sunflower is often sown and where most of the long-term tillage studies were conducted.

Little information was available on how hybrids of different maturity groups respond or interact with various tillage systems and no significant effect of tillage $\mathrm{x}$ hybrid interaction was generally found on grain yield (Deibert, 1989; Halvorson et al., 1999).

Quiroz et al. (2008) in Argentina demonstrated that the combination of no tillage and genetic resistance reduced the effect of Verticillium wilt of sunflower and the production of microsclerotia in stem pith to very low values. The choice of a cultivar could be modulated by the biotic risks associated to the tillage system.

\subsection{Agroforestry}

The agroforestry systems consist of associating forest trees with annual crops simultaneously, resulting in less dependence on inputs, greater food security and allowing the achievement of a greater number of products in the same area (Torralba et al., 2016). However, the forestry component may adversely affect the yield of agricultural crops in the agroforestry systems. Furthermore, the reduction in photosynthetically active radiation during the grain filling causes a decrease in oil production in sunflower (Aguirrezábal et al., 2003). In spite of 
the societal interest for such sustainable production systems, very few papers reported successful tree-sunflower intercropping results (e.g. Ramshe et al., 1994 for India).

de Oliveira et al. (2012) evaluated the effect of shading, caused by eucalyptus, on sunflower yield for 3 cultivars in an agroforestry system in Brazil. The shading caused by the trees created ideal conditions for the increased incidence of sclerotinia white rot in sunflower and induced a negative effect on the mean LAI, both resulting in a decline of sunflower yield of ca. $60 \%$. Therefore, intercropping with sunflower can be feasible only in the first years of implementation of the agroforestry system. Disease tolerance, adaptation to shading, rooting depth, response to plant density should be relevant traits to consider when evaluating the potential interest of a sunflower genotype for agroforestry.

\section{Ecosystem services other than production delivered by sunflower crop}

As was stated by several authors, sunflower has a potential for providing multiple ecosystem services (ES) in diverse cropping systems (Jones and Sieving, 2006; Franco et al., 2016; Debaeke et al., 2017a). In the absence of monetization, these ES should be widely emphasized to give more attractiveness to this low-input oilseed crop. We identified several services that could be filled by sunflower: (i) sustainment of biodiversity, by providing nutritional resources to pollinators; (ii) environment protection by a contribution to phytoremediation in heavy-metal polluted soils; (iii) pest regulation by a break effect in cereal rotations and by contributing to weed control in succeeding crops through allelopathy. The contribution of sunflower fields to the aesthetic value of landscapes should be also highlighted although this cultural service looks difficult to evaluate properly. Genetics could contribute to this service but, obviously, it doesn't deserve such an effort.

\subsection{Sunflower as a source of pollen and nectar for pollinators}

\subsubsection{Description of the service}

Beneficial insects, such as Apis mellifera (honey bees) and Bombus sp. (bumble bees), play important roles as sunflower pollinators. As well as being a service, pollination is a determinant process for successful seed set and yield in sunflower (Chabert et al., 2019).

In addition, it has been recognized for a long time that sunflower crop is a crucial source of pollen and nectar in early summer for the activity of the pollinators (Delaplane and Mayer, 2000). It generally offers abundant and accessible pollen and constitutes an additional source of pollen while floral nectar and other reward facilitate crop pollination (Nicolson and Human, 2013). Jones and Gillett (2005) indicated that sunflower sowings within rows of vegetable crops may be an effective way to attract beneficial insects into organic cropped fields in addition to bees.

Unfortunately, the pollinators are directly affected by agronomical practices, such as pesticide spraying or the selection of crop cultivar. Consequently, in France, sunflower honey production has decreased since the nineties and beekeepers reported important honey yield variability between years and locations (Cerrutti and Pontet, 2016). The nutritional needs of bees received renewed attention in the context of declining abundance and diversity of the insect populations and changes in land use that threaten floral resources. Giacomini et al. (2018) discovered that sunflower pollen dramatically reduced a protozoan pathogen (Crithidia bombi) infection in bumble bees (Bombus impatiens) and also reduced a microsporidian pathogen (Nosema ceranae) of the European honey bee (A. mellifera), indicating the potential for broad anti-parasitic effects. Given consistent effects of sunflower in reducing pathogens, sowing more sunflower in agroecosystems may provide a simple solution to reduce disease and improve the health of economically and ecologically important pollinators.

Therefore, all sunflower growers, and more especially producers of hybrid seeds, are concerned by pollinating insects. Wild and managed bees are needed to move sunflower pollen, both to create hybrid seed and to encourage high and consistent yields from these hybrids. Both for effective pollination and for nutritional value, the pollinators should be encouraged to visit sunflower at flowering. Specific traits should be evaluated for that. If differences among cultivars exist, farmers' choice concerning cultivars at a territory scale could contribute to enhance nectar resource for pollinators and to increase viability of apicultural activity.

\subsubsection{Varietal traits for this service}

Beekeepers have suggested that modern sunflowers would be less attractive than varieties grown 30 years ago. Therefore, pollinator attractivity is an important quality trait to be considered in sunflower breeding and registration programs (Terzic et al., 2017). For insect-pollinated crops, identifying and breeding for attractive floral traits may increase yields as well.

Cerrutti and Pontet (2016) assessed the attractiveness for honeybees of 13 current cultivars at blooming during 3 years. They concluded that sunflower genetics was a major and consistent factor influencing honeybee attendance on plots. Discrepancy between most and least visited cultivars reached a factor of 3 in this study. Similar results were obtained by Stejskalová et al. (2018). This could be potentially related to melliferous characteristics (Chabert et al., 2020) but also to other floral traits (Prasifka et al., 2018). Nicolson and Human (2013) indicated that the protein content of sunflower pollen is relatively low and the cultivars of such mass-flowering crops may also vary in value for pollinators.

For seriously addressing these questions, a lot of additional phenotyping would be necessary: pollen and nectar composition and secretion, tubular floret length (Vear, 2016; Chabert et al., 2020). Pollinators make foraging decisions based on numerous floral traits, including nectar and pollen rewards, and associated visual and olfactory cues (Mallinger and Prasifka, 2017). These authors observed that bee visits significantly increased with nectar sugar amount and decreased with corolla length, but appeared unaffected by nectar sugar composition. Portlas et al. (2018) concluded that among influential floral traits, floret size may be critical, as the depth of the corolla affects the accessibility of nectar. Therefore, production of 
inbreds and hybrids with smaller florets could enhance sunflower pollination. Genetic markers for key floral traits are needed to facilitate selection, and an understanding of potential trade-offs between traits is also required. Selecting for these traits could thus increase sunflower crop yields while providing greater floral resources for bees.

\subsection{Soil phytoremediation}

Accumulation of heavy metals (HMs) in soils as a result of various industrial and anthropogenic activities has reduced soil fertility significantly in some regions. It contributes to the contamination of agricultural crops then to the transfer of HMs into the food chain. Phytoremediation (or phytoextraction of $\mathrm{HMs}$ ) is an emerging method of remediating metal-contaminated soils which can improve soil fertility and provide inexpensive feedstock for biorefineries (Awa and Hadibarata, 2020).

Sunflower can be used efficiently for phytoextraction thanks to its high biomass production, its capacity for metal accumulation and because its oil can be used for non-food purpose thus improving the economic balance of the process (Angelova et al., 2016; Rizwan et al., 2016; Alaboudi et al., 2018). Sunflowers can tolerate the toxic effects of certain HMs through different mechanisms, this tolerance varying with variety, soil type, metal type, dose, and duration of metal exposure. The hyperaccumulation capacity of sunflower biomass was experimentally demonstrated by cultivating the plants in various concentrations of HMs. Nehnevajova et al. (2005) observed highly significant differences for metal accumulation and extraction efficiency among 15 cultivars grown on metal-contaminated soil. In this field-based screening, the authors found enhanced cumulative $\mathrm{Cd}, \mathrm{Zn}$, and $\mathrm{Pb}$ extraction efficiency by a factor 4.4 for cv. Salut.

Prior to any breeding attempt, a careful screening of various genotypes should be done to select the cultivars with the naturally highest metal uptake as an effective strategy for the phyto-management of soils contaminated with HMs. This hyperaccumulation activity could also be used to extract and concentrate essential elements (e.g. selenium) through biofortification in order to improve human nutrition (Garousi et al., 2018).

\subsection{Break crop for pests, weeds and diseases and contribution to useful biodiversity}

Growing sunflower in rotation with other crops is of first importance for the sustainability of the cropping system. In making the decision to include sunflower in their rotations, farmers will have to consider impact on subsequent crop yields, as well as costs of production, market value of crop, impact on pest problems, and total productivity of all crops in the rotation (Nielsen et al., 1999).

Sunflower is usually grown in 3-4 year rotations with cereals (e.g. wheat, barley, maize, sorghum), soybean, oilseed rape and grain legumes (Johnston et al., 2002; Lecomte and Nolot, 2011). However, it should not be grown too frequently to prevent the setting up of fungal diseases inoculum (e.g. phoma, phomopsis, downy mildew). Risks of sclerotinia could be enhanced also when increasing the proportion of some host plants in the rotation (e.g. pea, oilseed rape and soybean) (Debaeke et al., 2014).

The benefits of sunflower in nutrient cycling are wellknown. It acts as a "scavenger" crop as its deep root system can recover some of the nitrogen applied to the previous shallowrooted crop that has been leached to below its root zone (Angadi and Entz, 2002). Residual water left in the subsoil by previous crops can also be exploited by sunflower (Fereres et al., 1993; Cabelguenne and Debaeke, 1998). Sunflower reduces the potential for saline-seep development in dry environments (Halvorson et al., 1999). However, sunflower which extracts more water from the profile than other crops, leaves less water in the soil for the next crop which could be detrimental for yield in dry conditions (Cabelguenne and Debaeke, 1998; Anderson et al., 1999; Nielsen et al., 1999).

The fast degradation of sunflower cultural debris can deliver nutrients rapidly into the next crop (Rodriguez-Lizana et al., 2010; Babu et al., 2014) but $\mathrm{N}$ residual amount after sunflower is lower than after legumes (McEwen et al., 1989).

As a late spring-sown crop, sunflower could break winter crop rotations with benefits for the non-chemical control of weeds and soilborne diseases in winter cereals and oilseed rape (Colbach et al., 1994; Anderson et al., 1999). It proved to be effective in alleviating the "corn monoculture yield depression" (Porter et al., 1997). According to Jones and Sieving (2006), the addition of sunflower intercrops in organic vegetables proved to be an effective habitat modification for augmenting the number of avian insectivores and their insectforaging time. Intercropping sunflower with wheat contributed to the reduction of stripe rust and powdery mildew on wheat through a barrier effect (Cao et al., 2015).

The break potential of sunflower which is related to several plant characteristics has not been evaluated at the genotype level so far.

\subsection{Allelopathy}

The strategy of using allelopathic crop residues and water extracts for weed control seems to be a sustainable and friendly option to reduce dependence on herbicides. In addition to controlling weeds, residues of allelopathic crops positively affect soil health. Since the pioneer work of Leather (1983), numerous papers (about 40 in Web of Science) reported the allelopathic potential of sunflower plants and tissues in controlling weeds in sunflower and next crops with possible unwanted effects on subsequent crop species. This high allelopathic activity could be exploited more than currently done to reduce chemical weed control in sustainable agriculture. Several papers reviewed these effects (e.g. Gawronska et al., 2007; Albuquerque et al., 2011; Jabran, 2017) indicating that sunflower contains bioactive allelochemicals, especially phenolics and terpenoids, which would be involved in this suppressing effect.

Sunflower shows inhibitory effects on a relatively wide range of weeds (dicots and grasses) as assayed under laboratory, greenhouse and field conditions. Allelopathy could be exploited for biocontrol in several ways, among others as biologically active mulch either scattered over the soil surface or mixed into the soil. Sunflower root exudates also inhibit weed seedling growth, but are less effective than leaf and stem 
P. Debaeke et al.: OCL 2021, 28, 29

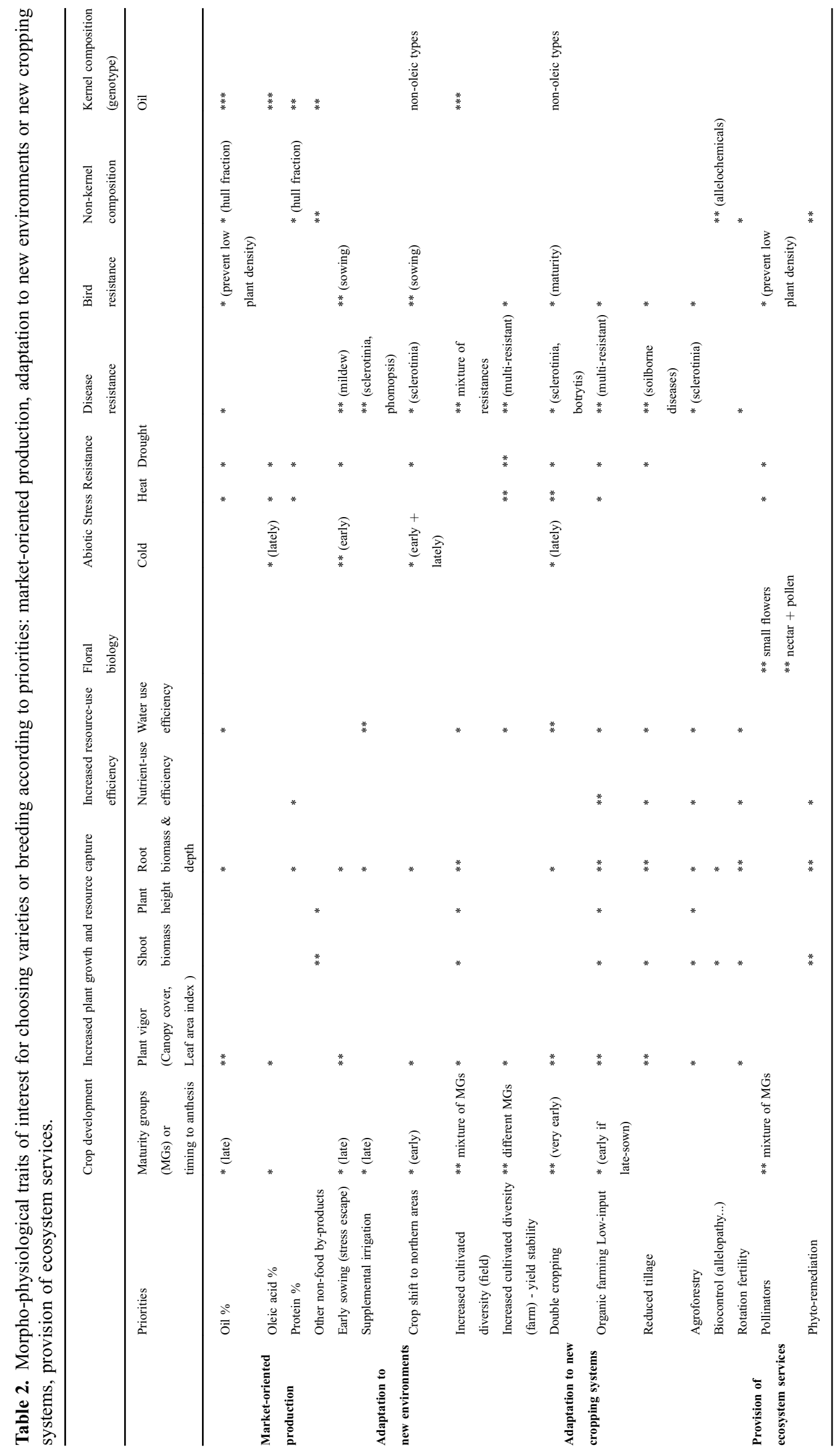

Page 14 of 23 
tissue leachates (Leather, 1983). Results indicated that application of sunflower water extracts reduced weed density by $5-26 \%$ and weed biomass by $9-31 \%$, while sunflower residue incorporation ( 4 to $6 \mathrm{t} / \mathrm{ha}$ ) caused $44-57 \%$ reduction in weed density and $58-70 \%$ reduction in weed biomass compared with the control (Ullah et al., 2018).

Genotypic variation, growing conditions, and various plant organs, such as leaves, stems and inflorescences may influence the allelopathic activity of sunflower, which can be both stimulatory (at low concentrations) and inhibitory (Gawronska et al., 2007). Different allelopathic activities were observed among a small set of sunflower hybrids (Anjum and Bajwa, 2008; Silva et al., 2009; Alsaadawi et al., 2012; Ullah et al., 2018). The total concentration of phytotoxins (phenolic compounds) was found to be higher in the most-suppressive potential genotypes compared with the least-suppressive ones.

\section{Challenges for designing and breeding sunflower ideotypes to face new and multiple objectives}

As climatic conditions, crop practices and cropping systems are changing markedly and because new ecosystem services are expected from sunflower crop, this requires a complete overhaul of the characteristics of the current varieties and justifies the exploration of new traits and the design and breeding of new ideotypes to make the crop better adapted to these emerging challenges.

In Table 2, we proposed a synthetic chart crossing priorities (targets) for management and breeding as described on Figure 1 and morpho-physiological traits of interest to consider and combine. From this table, we can conclude that some traits should be considered for a wide range of objectives (columns): root biomass and depth, canopy cover and plant vigor, phenology, disease resistance, drought-resistance. Some of them (phenology, disease resistance) have been already actively improved by breeders, but the other ones should be considered more for adapting sunflower to new environments and cropping systems. When looking at the rows, the main traits to combine when designing an ideotype for a given priority are suggested (see previous sections for more details). For instance, designing ideotypes for organic farming, double cropping or maximal oil production will have to optimize numerous criteria while phytoremediation or biocontrol will concentrate on specific plant characteristics.

Therefore, these changes in agricultural systems renew the potential interest of ideotype breeding (Gauffreteau, 2018). Donald (1968) first defined an ideotype as a "biological model which is expected to perform or behave in a predictable manner within a defined environment". In ideotype breeding, the relation between crop yield and its determining factors is implicitly modeled. In this case, a crop ideotype is mainly defined at the plant level, focusing on plant traits desirable to achieve a given objective. Because of increased knowledge in crop physiology, and developments in crop modeling and operational research, ideotype breeding can be pursued with greater formalization, potentially giving this approach an edge over classical breeding to tackle crop adaptation to new contexts (Martre et al., 2015).
Recent and diverse methodological approaches applied to sunflower (e.g. phenotyping, crop modeling, genomic prediction, multi-goal optimization, participatory breeding...) could be useful for the exploration and design of ideotypes (e.g. Picheny et al., 2017a, 2017b; Vincourt and Carolo, 2018; Gosseau et al., 2019; Debaeke et al., 2020). The existence of important wild and cultivated genetic resources in sunflower should facilitate the adaptation to this new context as well (Vear, 2016; Seiler et al., 2017; Terzić et al., 2020).

In major crops, genomic prediction (GP) approaches are used to select best lines for complex traits (Heslot et al., 2015). However, as genotyping and phenotyping technologies become available and cheaper, it creates new avenues for predictive approaches and enables their expansion to new crops and in smaller breeding programs (Ramstein et al., 2019). Genomic prediction was successfully applied for sunflower hybrids in an incomplete factorial design to predict oil yield (Mangin et al., 2017) and GP is now widely used in the main sunflower breeding companies.

A key challenge yet to solve is to predict the performance of novel hybrids in different pedo-climatic environments and with different crop practices. To achieve this, predictive approaches bridging quantitative genetics and crop modeling (Bustos-Korts et al., 2016) are under development to scale traits from the molecular to the crop level. Such approaches provide a unique way forward in defining an ideotype as a combination of genetic markers and not only as an addition of desired morpho-physiological and phenological traits.

One option is to process in two steps: firstly, to use GP to estimate a set of component traits, and then use a crop simulation model to predict performance-related traits as a function of environmental data (e.g. Chenu et al., 2009 for maize; Quilot-Turion et al., 2016, for peach tree). Typically, the genetically studied traits should encompass variables from both the real and the modelled system. For sunflower, such analysis can be conducted using the Phenotoul-Heliaphen high-throughput phenotyping platform (www.inrae.fr/phenotoul, Gosseau et al., 2019) that enables automatic estimation of the responses of leaf expansion and transpiration ratios to soil water deficit used as drought stress sensitivity proxies in the SUNFLO crop model (Casadebaig et al., 2008). The genetic analysis of the input parameters of the model, either to estimate allelic effects of QTLs or to train a large population for GP, relies on the high-throughput genotyping and phenotyping capacities (Cobb et al., 2013).

Breeding tools to select for the traits of interest have been revolutionized in the last decade with the first high-quality genomic sequence (Badouin et al., 2017), the use of resequencing and high-throughput genotyping arrays and the identification of numerous markers associated to QTLs or even the first cloning by fine-mapping of an Orobanche resistance gene (Duriez et al., 2019). New developments, including long-read sequencing and ever-cheaper short-read resequencing data are giving access to structural variations and genetic diversity in larger collections (Hübner et al., 2019; Todesco et al., 2020), that facilitates the identification of markers for breeding.

In the same time, the current revolution in phenomics is giving access to high-throughput automatic acquisition of images and 3D scans of sunflower plants and organs in 
controlled conditions under different biotic or abiotic stresses but also in field conditions. However, image and signal processing pipelines to estimate most of the classical traits are yet to be developed and the evaluation of new traits are pending.

In this context, the challenges to move from the identification of candidate traits (the purpose of this article) to the cultivation of varieties fulfilling climate change and societal demands are multiple.

First, research efforts should be deployed in the phenomics field to automatically measure traits used in the current registration system (Tab. 1) on a wide range of genetic material and environmental conditions including new cropping systems. This should allow to develop more complete sets of genetic markers for breeding including haplotypic variants, but also to study the stability of these traits in response to different stresses. In addition, phenomics procedures should be developed to characterize new traits such as yield plasticities for abiotic and biotic stresses, attractiveness to pollinators or phytoremediation. Performed systematically on a large extent of the genetic resources and in the registration process, and supported by crop simulation, this would provide information for breeders and possibly farmers. This could also justify a reshaping of the current experimental networks by diversifying the testing environments and the crop management systems.

To exploit the increasingly large and complex phenotypic and genotypic data, we can clearly identify as well a challenge for the sunflower community to organize them under the FAIR principles. Initiatives from the French community to archive sequencing and phenotyping data (https://sunrise-archive. toulouse.inra.fr/web/index.html) should be consolidated and amplified to an international level. Thanks to the recently released sunflower Crop Ontology, an international database for both resources should be created and made available to public and private research.

The ambitious goal to better adapt the choice of varieties also necessitates to better characterize the biotic and abiotic environments of the registration and post-registration multienvironment trials using more systematically simulation models and sensors. This would enable the estimation of infra-specific yield plasticities (i.e. sensitivity to abiotic stresses) like in Mangin et al. (2017).

\section{Conclusion}

As was reviewed, many traits are possibly relevant when designing and breeding sunflower varieties better adapted to climate change, new ecological cropping systems and providing ecosystem services (Tab. 2). This implies to produce many different varieties adapted to contrasting and fluctuating environments or needs (markets, services) and to combine the desired traits by stacking faster and more efficiently.

Research and innovation will have to share their efforts between different and multiple breeding targets and agroenvironmental conditions, in the context of a strong market segmentation (Pilorgé, 2020) and priorities will have to be established among the numerous and sometimes opposite breeding objectives identified for sustainable production (Kaya, 2016).
The challenges faced by the sunflower research community are important and include the development of resources and methods, their transfer to the breeding sector and also the improvement of the registration and recommendation devices to finally provide to farmers a larger panel of varieties with more complete and accessible information including possibly new traits related to stress tolerance and ecosystem services.

Acknowledgements. Research grants were provided by the French Ministry of Research (ANR SUNRISE ANR-11BTBR-0005) and by European Union's Horizon 2020 research and innovation program under grant agreement No. 817970 (INVITE). The two multi-partners projects INVITE and SUNRISE inspired and supported the ideas developed in this review. We also thank Léonie Langlade for the sunflower painting in Figure 1.

\section{References}

Ada R, Tamkoç A. 2015. Determination of some agricultural characteristics in the sunflower genotypes developed as second crop. Selcuk J Agric Food Sci 29: 44-50.

Adiredjo A, Navaud O, Munos S, Langlade N, Lamaze T, Grieu P. 2014. Genetic control of water use efficiency and leaf carbon isotope discrimination in sunflower (Helianthus annuus L.) subjected to two drought scenarios. PLoS One 9: e0101218.

Akcay S, Dagdelen N. 2016. Water use efficiency, yield and yield components of second crop sunflower under deficit irrigation. Turk J Field Crops 21: 190-199.

Aguirrezábal LAN, Tardieu F. 1996. An architectural analysis of the elongation of the field grown sunflower root system. Elements for modeling the effects of temperature and intercepted radiation. $J$ Exp Bot 47: 411-420.

Aguirrezábal LAN, Lavaud Y, Dosio GA, Izquierdo NG, Andrade FH, Gonzalez LM. 2003. Intercepted solar radiation during seed filling determines sunflower weight per seed and oil concentration. Crop Sci 43: 152-161.

Ahmad RT, Waraich EA, Ashraf MY, Ahmad S, Aziz T. 2014. Does Nitrogen fertilization enhance drought tolerance in sunflower? A review. J Plant Nutr 37: 942-963.

Alaboudi KA, Ahmed B, Brodie G. 2018. Phytoremediation of Pb and $\mathrm{Cd}$ contaminated soils by using sunflower (Helianthus annuus) plant. Ann Agric Sci 63: 123-127.

Albuquerque M, Santos R, Lima L, Melo Filho P, Nogueira R, Ramos CC. 2011. Allelopathy, an alternative tool to improve cropping systems. A review. Agric Syst Dev 31: 379-395.

Alline C, Ghoribi N, Maury P, et al. 2008. Early sowing as a means of drought escape in sunflower: effects on vegetative and reproductive stages. In: Proc 17th Int Sunf Conf, Cordoba, Spain.

Alline C, Maury P, Sarrafi A, Grieu P. 2009. Genetic control of physiological traits associated to low temperature growth in sunflower under early sowing conditions. Plant Sci 177: 349-359.

Alline C, Maury P, Debaeke P, Sarrafi A, Grieu P. 2010. Indicateurs physiologiques pour le screening de génotypes de tournesol tolérants aux basses températures associées au semis précoce. OCL - Oilseeds \& fats Crops and Lipids 17: 167-170.

Alsaadawi IS, Sarbout AK, Al-Shamma LM. 2012. Differential allelopathic potential of sunflower (Helianthus annuus L.) genotypes on weeds and wheat (Triticum aestivum L.) crop. Arch Agron Soil Sci 58: 1139-1148.

Anderson RL, Bowman RA, Nielsen DC, Vigil MF, Aiken RM, Benjamin JG. 1999. Alternative crop rotations for the central Great Plains. J Prod Agric 12: 95-99. 
Andrade JF, Cerrudo A, Rizzalli RH, Monzon JP. 2012. Sunflowersoybean intercrop productivity under different water conditions and sowing managements. Agron J 104: 1049-1055.

Andrianasolo FN, Debaeke P, Champolivier L, Maury P. 2016. Analysis and modelling of the factors controlling seed oil content in sunflower: a review. OCL 23(2): D206.

Angadi SV, Entz MH. 2002. Root system and water use patterns of different height sunflower cultivars. Agron J 94: 136-145.

Angelova VR, Perifanova-Nemska MN, Uzunova GP, Ivanov KI, Lee HQ. 2016. Potential of sunflower (Helianthus annuus L.) for phytoremediation of soils contaminated with heavy metals. Int $J$ Environ Ecol Eng 10: 576-583.

Anjum T, Bajwa R. 2008. Screening of sunflower varieties for their herbicidal potential against common weeds of wheat. J Sustain Agric 31: 213-229.

Astiz V, Hernandez LF. 2013. Pollen production in sunflower (Helianthus annuus L.) is affected by air temperature and relative humidity during early reproductive growth. Phyton 82: 297-302.

Attia Z, Pogoda CS, Reinert S, Kance NC, Hulke BS. 2021. Breeding for sustainable oilseed crop yield and quality in a changing climate. Theor Appl Genet. Published online: 21 Jan 2021. https:// doi.org/10.1007/s00122-021-03770-w.

Awa SH, Hadibarata T. 2020. Removal of heavy metals in contaminated soil by phytoremediation mechanism: a review. Water Air Soil Pollut 231: 47.

Ayerdi-Gotor A, Berger M, Lablette F, Centis S, Dayde J, Calmon A. 2015. Comparative analysis of fatty acids, tocopherols and phytosterols content in sunflower cultivars (Helianthus annuus) from a three-year multi-local study. Phyton 84: 14-25.

Awais M, Wajid A, Saleem MF, et al. 2018. Potential impacts of climate change and adaptation strategies for sunflower in Pakistan. Environ Sci Pollut Res Int 25: 13719-13730.

Babu S, Rana DS, Yadav GS, Singh R, Yadav SK. 2014. A review on recycling of sunflower residue for sustaining soil health. Int J Agron, ID601049.

Badouin H, Gouzy J, Grassa CJ, et al. 2017. The sunflower genome provides insights into oil metabolism, flowering and Asterid evolution. Nature 546(7656): 148.

Bahrani MJ, Bamdad N, Kazemeini SA. 2009. Yield and yield structures of irrigated sunflower cultivars as influenced by tillage and wheat residue management systems. Arch Agron Soil Sci 55: 507-514.

Baligar VC, Fageria NK, He ZL. 2001. Nutrient use efficiency in plants. Commun Soil Sci Plant Anal 32: 921-950.

Barot S, Allard V, Cantarel A, et al. 2017. Designing mixtures of varieties for multifunctional agriculture with the help of ecology. A review. Agron Sust Dev 37(2): 13.

Barros JFC, De Carvalho M, Basch G. 2004. Response of sunflower (Helianthus annuus L.) a sowing date and plant density under Mediterranean conditions. Eur J Agron 21: 347-356.

Bellarby J, Wattenbach M, Tuck G, Glendining MJ, Smith P. 2010. The potential distribution of bioenergy crops in the UK under present and future climate. Biomass Bioenerg 34: 1935-1945.

Blackman BK, Rasmussen DA, Strasburg JL, et al. 2011. Contributions of flowering time genes to sunflower domestication and improvement. Genetics 187: 271-287.

Blum A. 2005. Drought resistance, water-use efficiency, and yield potential - are they compatible, dissonant, or mutually exclusive? Aust J Agric Res 56: 1159-1168.

Borredon ME, Berger M, Dauguet S, et al. 2011. Débouchés actuels et futurs du tournesol produit en France - Critères de qualité. Innovations Agronomiques 14: 19-38.
Boujghagh M. 1993. Comportement de dix génotypes de tournesol en semis d'hiver dans trois sites pédoclimatiques marocains. Helia 16(19): 31-44.

Bremner PM, Preston GK, Fazekas de St Groth C. 1986. A field comparison of sunflower (Helianthus annuus) and sorghum (Sorghum bicolor) in a long drying cycle. I. Water extraction. Aust J Agric Res 37: 483-493.

Bustos-Korts D, Malosetti M, Chapman S, van Eeuwijk F. 2016. Modelling of genotype by environment interaction and prediction of complex traits across multiple environments as a synthesis of crop growth modelling, genetics and statistics. In: Yin X, Struick PC, eds. Crop Systems Biology. Switzerland: Springer International Publishing, pp 55-82.

Cabelguenne M, Debaeke P. 1998. Experimental determination and modelling of the soil water extraction capacities of maize, sunflower, soybean, sorghum and wheat. Plant Soil 202: 175-192.

Cadic E, Coque M, Vear F, et al. 2013. Combined linkage and association mapping of flowering time in sunflower (Helianthus annuus L.). Theor Appl Genet 126: 1337-1356.

Cabelguenne M, Debaeke P. 1998. Experimental determination and modelling of the soil water extraction capacities of maize, sunflower, soybean, sorghum and wheat. Plant Soil 202: 175-192.

Canavar Ö, Götz KP, Ellmer F, Chmielewski FM, Kaynak MA. 2014. Determination of the relationship between water use efficiency, carbon isotope discrimination and proline in sunflower genotypes under drought stress. Aust J Crop Sci 8: 232-242.

Cantagallo JE, Medan D, Hall AJ. 2004. Grain number in sunflower as affected by shading during floret growth, anthesis and grain setting. Field Crops Res 85: 191-202

Cao S, Luo H, Jin M, et al. 2015. Intercropping influenced the occurrence of stripe rust and powdery mildew in wheat. Crop Prot 70: $40-46$.

Casadebaig P, Debaeke P. 2011. Using a crop model to assess genotype-environment interactions in multi-environment trials. Aspects of Applied Biology 107, Systems Approaches to Crop Improvement. Wellesbourne, UK: Association of Applied Biologists, pp 19-25.

Casadebaig P, Debaeke P, Lecoeur J. 2008. Thresholds for leaf expansion and transpiration response to soil water deficit in a range of sunflower genotypes. Eur J Agron 28: 646-654.

Casadebaig P, Guilioni L, Lecoeur J, Christophe A, Champolivier L, Debaeke P. 2011. SUNFLO, a model to simulate genotypespecific performance of the sunflower crop in contrasting environments. Agric For Meteorol 151: 163-178.

Casadebaig P, Mestries E, Debaeke P. 2016. A model-based approach to assist variety evaluation in sunflower crop. Eur J Agron 81: 92-105.

Champolivier L, Debaeke P, Merrien A. 2011. Pourquoi irriguer le tournesol, une culture réputée tolérante à la sécheresse? Innovations Agronomiques 14: 151-164.

Cerrutti N, Pontet C. 2016. Differential attractiveness of sunflower cultivars to the honeybee Apis mellifera L. OCL 23(2): D204.

Chabert S, Sénéchal C, Benoist A, et al. 2019. Tournesol: la pollinisation au service du rendement. Phytoma 729: 45-49.

Chabert S, Sénéchal C, Fougeroux A, et al. 2020. Effect of environmental conditions and genotype on nectar secretion in sunflower (Helianthus annuus L.). OCL 27: 51.

Chenu K, Chapman SC, Tardieu F, McLean G, Welcker C, Hammer GL. 2009. Simulating the yield impacts of organ-level quantitative trait loci associated with drought response in maize: a "geneto-phenotype" modeling approach. Genetics 183: 1507-1523. 
Chervet B, Vear F. 1990. A study of the relations between earliness in sunflowers and yield, oil content, development and morphology. Agronomie 10: 51-56.

Chimenti CA, Hall AJ. 1993. Genetic variation and changes with ontogeny of osmotic adjustment in sunflower (Helianthus annuus L.). Euphytica 71: 201-210.

Chimenti CA, Hall AJ. 1994. Responses to water-stress of apoplastic water fraction and bulk modulus of elasticity in sunflower (Helianthus annuus L.) genotypes of contrasting capacity for osmotic adjustment. Plant Soil 166: 101-107.

Chimenti CA, Hall AJ. 2001. Grain number responses to temperature during floret differentiation in sunflower. Field Crops Res 72: 177-184.

Chimenti CA, Hall AJ, Lopez MS. 2001. Embryo-growth rate and duration in sunflower as affected by temperature. Field Crops Res 69: 81-88.

Chimenti CA, Pearson J, Hall AJ. 2002. Osmotic adjustment and yield maintenance under drought in sunflower. Field Crops Res 75: 235-246.

Clark RB, Duncan RR. 1991. Improvement of plant mineral nutrition through breeding. Field Crop Res 27: 219-240.

Cobb JN, DeClerck G, Greenberg A, Clark R, McCouch S. 2013. Next-generation phenotyping: requirements and strategies for enhancing our understanding of genotype-phenotype relationships and its relevance to crop improvement. Theor Appl Genet 126: 868-887.

Colbach N, Lucas P, Cavelier N. 1994. Influence des successions culturales sur les maladies du pied et des racines du blé d'hiver. Agronomie 14: 525-540.

Comas LH, Becker SR, Cruz VM, Byrne PF, Dierig DA. 2013. Root traits contributing to plant productivity under drought. Front Plant Sci 4: 442.

Connor DJ, Jones TR. 1985. Response of sunflower to strategies of irrigation. II. Morphological and physiological responses to water stress. Field Crops Res 12: 91-103.

Connor DJ, Hall A. 1997. Sunflower physiology. In: Schneiter AA, ed. Sunflower Technology and Production. Agronomy Monograph 35. Madison, WI: ASA, CSSA and SSSA, pp. 113-182.

Cox WJ, Jolliff GD. 1986. Growth and yield of sunflower and soybean under soil water deficits. Agron J 78: 226-230.

Cox WJ, Jolliff GD. 1987. Crop-water relations of sunflower and soybean under irrigated and dryland conditions. Crop Sci 27: $553-557$.

Dalchiavon FC, Portela de Carvalho CG, Amabile RF, Campos Godinho VP, Ramos NP, Anselmo JL. 2016. Agronomic traits and their correlations in sunflower hybrids adapted to second crop. Pesq Agropec Bras 51: 1806-1812.

Dalla Costa L, Giovanardi R. 1996. Nitrogen use efficiency and nitrate losses in sunflower and maize: a comparison. In: Proc 14th Int Sunf Conf, ISA, Beijing, China.

Dardanelli JL, Bachmeier R, Sereno R, Gil R. 1997. Rooting depth and soil water extraction patterns of different crops in a silty loam haplustoll. Field Crops Res 54: 29-38.

Dauguet S, Labalette F, Fine F, Carré P, Merrien A, Palleau JP. 2016. Genetic impact on protein content and hullability of sunflower seeds, and on the quality of sunflower meal. OCL 23(2): D205.

Debaeke P, Bertrand M. 2008. Évaluation des impacts de la sécheresse sur le rendement des grandes cultures en France. Cah Agric 17: 437-443.

Debaeke P, Izquierdo NG. 2021. Sunflower. In: Sadras VO, Calderini D, eds. Crop Physiology: Case Histories for Major Crops, 1st ed. Elsevier Inc., pp 483-517.
Debaeke P, Cabelguenne M, Hilaire A, Raffaillac D. 1998. Crop management systems for rainfed and irrigated sunflower (Helianthus annuus) in southwestern France. J Agric Sci Camb 131: 171-185.

Debaeke P, Casadebaig P, Haquin B, Mestries E, Palleau JP, Salvi F. 2010. Simulation de la réponse variétale du tournesol à l'environnement à l'aide du modèle SUNFLO. OCL 17(3): 143-151.

Debaeke P, Casadebaig P, Mestries E, et al. 2011. Évaluer et valoriser les interactions variété-milieu-conduite en tournesol. Innovations Agronomiques 14: 77-90.

Debaeke P, Mestries E, Desanlis M, Seassau C. 2014. Effects of crop management on the incidence and severity of fungal diseases in sunflower. In: Arribas JE, ed. Sunflowers: Growth and Development, Environmental Influences and Pests/Diseases. New York, USA: Nova Science Pubs, pp 201-226.

Debaeke P, Bedoussac L, Bonnet C, et al. 2017a. Sunflower crop: environmental-friendly and agroecological. OCL 24(3): D304.

Debaeke P, Casadebaig P, Flénet F, Langlade N. 2017b. Sunflower crop and climate change: vulnerability, adaptation, and mitigation potential from case-studies in Europe. OCL 24(1): D102.

Debaeke P, Bret-Mestries E, Aubertot JN, et al. 2020. Sunflower agronomy: 10 years of research in partnership within the "Sunflower" Technological Joint Unit (UMT) in Toulouse. OCL 27: 14.

Deibert EJ. 1989. Reduced tillage system influence on yield of sunflower hybrids. Agron J 81: 274-279.

Delaplane KS, Mayer DF. 2000. Crop pollination by bees. New York: CABI.

Deppermann A., Balkovic J, Bundle SC, et al. 2018. Increasing crop production in Russia and Ukraine - regional and global impacts from intensification and recultivation. Environ Res Lett 13: 025008 .

Donald CM. 1968. The breeding of crop ideotype. Euphytica 17: 385-403.

Donatelli M, Srivastava AK, Duveiller G, Niemeyer S, Fumagalli D. 2015. Climate change impact and potential adaptation strategies under alternate realizations of climate scenarios for three major crops in Europe. Environ Res Lett 10: e75005.

Dragovic S, Maksimovic L, Panic Z, Skoric D. 1992. Double cropping irrigated sunflower in the Vojvodina province. In: Proc 12th Int Sunf Conf, ISA, Pisa, Italy.

Dunford NT. 2015. Oxidative stability of sunflower seed oil. In: Martínez-Force E, Dunford NT, Salas JJ, eds. Sunflower: Chemistry, Production, Processing, and Utilization. Monograph Series on Oilseeds. Urbana (Illinois): AOCS Press, pp 465-489.

Duriez P, Vautrin S, Auriac M-C, et al. 2019. A receptor-like kinase enhances sunflower resistance to Orobanche cumana. Nature Plants 5: 1211-1215.

Duru M. 2019. Trends in agri-food choices for health since the 1960s: the case of fatty acids. OCL 26: 44.

Duru M, Magrini MB. 2017. Polyunsaturated fatty acids composition of our meals and use of agricultural raw products in France: a slow improvement, but not sufficient. OCL 24(2): A201.

Duru M, Therond O, Martin G, et al. 2015. How to implement biodiversity-based agriculture to enhance ecosystem services: a review. Agric Sustain Dev 35: 1259-1281.

Echarte MM, Angeloni P, Jaimes F, et al. 2010. Night temperature and intercepted solar radiation additively contribute to oleic acid percentage in sunflower oil. Field Crops Res 119: 27-35

Echarte L, Della Maggiora A, Cerrudo D, et al. 2011. Yield response to plant density of maize and sunflower intercropped with soybean. Field Crops Res 121: 423-429. 
Fabio EA, Tommasino EA, Cantarero M, Luque S. 2016. Physiological basis and antioxidant activity in cold stress recover in sunflower (Helianthus annuus L.). In: Proc 19th Int Sunf Conf, ISA, Edirne, Turkey.

Fereres E, Gimenez C, Fernandez JM. 1986. Genetic variability in sunflower cultivars under drought. I. Yield relationships. Aust J Agric Res 37: 573-582.

Fereres E, Orgaz E, Villalobos FJ. 1993. Water use efficiency in sustainable agricultural systems. In: Shibles $\mathrm{R}$, et al., eds. International Crop Science. Vol. I. Madison, WI: CSSA, pp. 83-89.

Fernandez MC, Rubio G. 2015. Root morphological traits related to phosphorus-uptake efficiency of soybean, sunflower, and maize. J Plant Nutr Soil Sci 178: 807-815.

Fick GN, Miller JF, 1997. Sunflower breeding. In: Schneiter AA, ed. Sunflower Production and Technology. Madison, WI: ASA, pp. $395-440$.

Flagella Z, Rotunno T, Di Tarantino E, Caterina R, De Caro A. 2002. Changes in seed yield and oil fatty acid composition of high oleic sunflower (Helianthus annuus L.) hybrids in relation to the sowing date and the water regime. Eur J Agron 17: 221-230.

Franco JG, Saliendra N, Sanderson M, Liebig M, Archer D. 2016. Long-term agroecosystem research: the potential for sunflower to provide multiple ecosystem services in diverse cropping systems. Fargo (ND), USA: National Sunflower Association Research Forum.

de la Fuente EB, Suárez SA, Lenardis AE, Poggio SL. 2014. Intercropping sunflower and soybean in intensive farming systems: evaluating yield advantage and effect on weed and insect assemblages. NJAS Wagening J Life Sci 70-71: 47-52.

García-López J, Lorite IJ, García-Ruiz R, Ordonez R, Dominguez J. 2016. Yield response of sunflower to irrigation and fertilization under semi-arid conditions. Agric Water Manag 176: 151-162.

García-Vila M, Fereres E, Prieto MH, Ruz C, Soriano MA. 2012. Sunflower. In: Crop yield response to water. FAO Irrigation and Drainage Paper 66.

Garousi F, Kovacs B, Veres S. 2018. Sunflower seedlings hyperaccumulate selenium. Acta Biol Hung 69: 197-209.

Gauffreteau A, 2018. Using ideotypes to support selection and recommendation of varieties. OCL 25(6): D602.

Gawronska H, Ciarka D, Bernat W, Gawronski SW. 2007. Sunflowerdesired allelopathic crop for sustainable and organic agriculture? In: Fujii Y, Hiradate S, eds. Allelopathy: New Concepts And Methodology. Enfield, CT, USA: Science Publishers, pp. 185-210.

Gesch RW, Archer DW. 2013. Double-cropping with winter camelina in the northern Corn Belt to produce fuel and food. Ind Crops Prod 44: 718-725.

Giacomini JJ, Leslie J, Tarpy DR, Palmer-Young EC, Irwin RE, Adler LS. 2018. Medicinal value of sunflower pollen against bee pathogens. Sci Rep 8: 14394.

Gimenez C, Fereres E. 1986. Genetic variability in sunflower cultivars under drought. II. Growth and water relations. Aust J Agric Res 37: 583-597.

Gimeno V, Fernández-Martínez JM, Fereres E. 1989. Winter planting as a means of drought escape in sunflower. Field Crops Res 22: 307-316.

Goksoy AT, Demir AO, Turan ZM, Dagustu N. 2004. Responses of sunflower (Helianthus annuus L.) to full and limited irrigation at different growth stages. Field Crops Res 87: 167-178.

González-Belo R, Tognetti J, Benech-Arnold R, Izquierdo NG. 2014. Germination responses to temperature and water potential as affected by seed oil composition in sunflower. Ind Crops Prod 62: 537-544.
Gosseau F, Blanchet N, Varès D, et al. 2019. Heliaphen, an outdoor high-throughput phenotyping platform for genetic studies and crop modeling. Front Plant Sci 9: 1908.

Gosset H, Vear F. 1995. Comparaison de la productivité du tournesol au Maroc en semis d'automne et en semis de printemps. Al Awamia 88: 5-20

Govaerts B, Verhulst N, Castellanos-Navarrete A, Sayre KD, Dixon J, Dendoven L. 2009. Conservation agriculture and soil carbon sequestration: between myth and farmer reality. Crit Rev Plant $S c i$ 28: $97-122$.

Goyne PJ, Schneiter AA, Cleary KC, Creelman RA, Stegmeier WD, Wooding FJ. 1989. Sunflower genotype response to photoperiod and temperature in field environments. Agron J 81: 826-831

Graß R, Heuser F, Stülpnagel R, Piepho HP, Wachendorf M. 2013. Energy crop production in double-cropping systems: results from an experiment at seven sites. Eur J Agron 51: 120-129.

Grassini P, Hall AJ, Mercau JL. 2009. Benchmarking sunflower water productivity in semiarid environments. Field Crops Res 110: 251262.

Guiducci M. 1988. Effect of water deficit on leaf area development and PAR absorption of a sunflower summer crop. In: Proc 12th Int Sunf Conf, ISA, Novi Sad, Yugoslavia.

Guilioni L, Lhomme JP. 2006. Modelling the daily course of capitulum temperature in a sunflower canopy. Agric For Meteorol 138: 258-272.

Gutierrez A, Cantamutto M, Poverene M. 2016. Cold stress tolerance during early growth stages of naturalized Helianthus petiolaris populations. Helia 39(64): 21-43.

de la Haba P, de la Mata L, Molina E, Agüera E. 2014. High temperature promotes early senescence in primary leaves of sunflower (Helianthus annuus L.) plants. Can J Plant Sci 94: 659-669.

Hall AJ, Feoli C, Ingaramo J, Balzarini M. 2013. Gaps between farmer and attainable yields across rainfed sunflower growing regions of Argentina. Field Crops Res 143: 119-129.

Halvorson AD, Black AL, Krupinsky JM, Merrill SD, Tanaka DL. 1999. Sunflower response to tillage and nitrogen fertilization under intensive cropping in a wheat rotation. Agron J91:637-642.

Hattendorf MJ, Redelfs MS, Amos B, Stone LR, Gwin Jr RE. 1988. Comparative water use characteristics of six row crops. Agron $J$ 80: 80-85.

Hernández LF, Orioli GA. 1985. Relationships between root permeability to water, leaf conductance and transpiration rate in sunflower Helianthus annuus L. cultivars. Plant Soil 85: 229-235.

Hernandez F, Poverene M, Mercer KL, Presotto A. 2020. Genetic variation for tolerance to extreme temperatures in wild and cultivated sunflower (Helianthus annuus) during early vegetative phases. Crop Past Sci 71: 578-591.

Heslot N, Jannink JL, Sorrell ME. 2015. Perspectives for genomic selection applications and research in plants. Crop Sci 55: $1-12$.

Hewezi T, Léger M, El Kayal W, Gentzbittel L. 2006. Transcriptional profiling of sunflower plants growing under low temperatures reveals an extensive down-regulation of gene expression associated with chilling sensitivity. J Exp Bot 57: 3109-3122.

Hniličková H, Hejnák V, Němcová L, et al. 2017. The effect of freezing temperature on physiological traits in sunflower. Plant Soil Environ 63: 375-380.

Houmanat K, El Fechtali M, Mazouz H, Nabloussi A. 2016. Evaluation and selection of promising sunflower germplasm under early winter planting conditions. Afr J Agric Res 11: 4610-4611. 
Hübner S, Bercovich N, Todesco M, et al. 2019. Sunflower pangenome analysis shows that hybridization altered gene content and disease resistance. Nature Plants 5: 54-62.

Hulke BS, May WE. 2018. Registration of Oilseed Sunflower Restorer Germplasms RHA 476 and RHA 477, Adapted for Short Season Environments. Journal of Plant Registrations 12: 148151. Fargo (ND): USDA.

Hussain M, Farooq S, Hasan W, et al. 2018. Drought stress in sunflower: physiological effects and its management through breeding and agronomic alternatives. Agric Water Manag 201: $152-166$.

Hussain MM, Rauf S, Warburton ML. 2019. Development of droughttolerant breeding lines derived from Helianthus annuus $\mathrm{x}$ H. argophyllus interspecific crosses. Plant Breed 138: 862-870.

IPCC. 2014. Climate Change 2014: Synthesis Report. In: Core Writing Team, Pachauri RK, Meyer LA, eds. Contribution of Working Groups I, II and III to the Fifth Assessment Report of the Intergovernmental Panel on Climate Change. Geneva, Switzerland: IPCC, $151 \mathrm{p}$.

Izquierdo NG, Aguirrezábal L, Andrade F, Pereyra V. 2002. Night temperature affects fatty acid composition in sunflower oil depending on the hybrid and the phenological stage. Field Crops Res 77: 115-126.

Izquierdo NG, Dosio GAA, Cantarero M, Lujan J, Aguirrezabal LAN. 2008. Weight per grain, oil concentration, and solar radiation intercepted during grain filling in black hull and striped hull sunflower hybrids. Crop Sci 48: 688-699.

Jabran K. 2017. Sunflower allelopathy for weed control. In: Jabran K, ed. Manipulation of Allelopathic Crops for Weed Control. Springer Briefs in Plant Science. Switzerland: Springer International Publishing AG, pp. 77-85.

Janmohammadi M, Zolla L, Rinalducci S. 2015. Low temperature tolerance in plants: changes at the protein level. Phytochem 11: 76-89.

Johnson B. 1971. Effect of weed competition on sunflowers. Weed Sci 19: $378-380$.

Johnston AM, Tanaka DL, Miller PR, et al. 2002. Oilseed crops for semiarid cropping systems in the Northern Great Plains. Agron J 94: 231-240.

Jones GA, Gillett JL. 2005. Intercropping with sunflowers to attract beneficial insects in organic agriculture. Florida Entomol 88: 91-96.

Jones GA, Sieving KE. 2006. Intercropping sunflower in organic vegetables to augment bird predators of arthropods. Agric Ecosyst Environ 117: 171-177.

Jouffret P, Labalette F, Thibierge J. 2011. Atouts et besoins en innovations du tournesol pour une agriculture durable. Innovations Agronomiques 14: 59-76.

Kalyar T, Rauf S, da Silva JAT, Iqbal Z. 2013. Variation in leaf orientation and its related traits in sunflower (Helianthus annuus L.) breeding populations under high temperature. Field Crop Res 150: 91-98.

Kandel HJ, Schneiter AA, Johnson BL. 1997. Intercropping legumes into sunflower at different growth stages. Crop Sci 37: 1532-1537.

Kantar MB, Sosa CC, Khoury CK, et al. 2015. Ecogeography and utility to plant breeding of the crop wild relatives of sunflower (Helianthus annuus L.). Front Plant Sci 6: 841.

Kaya Y. 2016. Sunflower. In: Gupta SK, ed. Breeding oilseed crops for sustainable production. Opportunities and constraints. Academic Press, Elsevier Inc., pp. 55-88.

Keipp K, Hütsch BW, Schubert S. 2019. How does the harvest index affect water-use efficiency and nutrient-utilization efficiency of sunflowers (Helianthus annuus L.)? J Agron Crop Sci 205: $519-532$.
Khalifa FM, Schneiter AA, El Tayeb EI. 2000. Temperaturegermination responses of sunflower (Helianthus annuus L.) genotypes. Helia 23(33): 97-104.

Kiani SP, Grieu P, Maury P, Hewezi T, Gentzbittel L, Sarrafi A. 2007. Genetic variability for physiological traits under drought conditions and differential expression of water stress-associated genes in sunflower (Helianthus annuus L.). Theor Appl Genet 114: 193-207.

Lambrides CJ, Chapman SC, Shorter R. 2004. Genetic variation for carbon isotope discrimination in sunflower: association with transpiration efficiency and evidence for cytoplasmic inheritance. Crop Sci 44: 1642-1653.

Landé N, Jouffret P, Tribouillois H, et al. 2012. Evaluating economic and technical performances of sunflower-soybean intercrop in French farming systems. In: Proc 18th Int Sunf Conf, ISA, Mar del Plata, Argentina.

Latify S, Yousefi AR, Jamshidi K. 2017. Integration of competitive cultivars and living mulch in sunflower (Helianthus annuus L.): a tool for organic weed control. Org Agric 7: 419-430.

Leather GR. 1983. Sunflowers (Helianthus annuus) are allelopathic to weeds. Weed Sci 31: 37-42.

Lecomte V. 2009. Tournesol et soja: réussir une culture dérobée. Persp Agric 357: 93-95.

Lecomte V, Nolot JM. 2011. Place du tournesol dans le système de culture. Innovations Agronomiques 14: 59-76.

Le Gall C. 2019. Panorama de l'offre variétale en tournesol - Évolution et perspectives. In: Les $2^{\text {es }}$ Rencontres des Grandes Cultures Bio, Paris, 22 janvier 2019, pp. 56-59.

Le Gall C, Lecomte V. 2019. Enquête Tournesol Bio 2017: un compromis à trouver entre différents objectifs. Persp Agric 464: 16-19.

Leon AJ, Andrade FH, Lee M. 2000. Genetic mapping of factors affecting quantitative variation for flowering in sunflower. Crop Sci 40: 404-407.

Leon AJ, Lee M, Andrade FH. 2001. Quantitative trait loci for growing degree-days to flowering and photoperiod response in sunflower (Helianthus annuus L.). Theor Appl Genet 102: 497503.

Lisanti S, Hall AJ, Chimenti CA. 2013. Influence of water deficit and canopy senescence pattern on Helianthus annuus (L.) root functionality during the grain-filling phase. Field Crops Res 154: 1-11.

Lopez-Bellido RJ, Lopez-Bellido L, Castillo JE, Lopez-Bellido FJ. 2002. Sunflower response to tillage and soil residual nitrogen in a wheat-sunflower rotation under rainfed Mediterranean conditions. Aust J Agric Res 53: 1027-1033.

McEwen J, Darb RJ, Hewitt MV, Yeoman DP. 1989. Effects of field beans, fallow, lupins, oats, oilseed rape, peas, ryegrass, sunflowers and wheat on nitrogen residues in the soil and on the growth of a subsequent wheat crop. J Agric Sci Camb 115: 209-219.

Mallinger RE, Prasifka JR. 2017. Bee visitation rates to cultivated sunflowers increase with the amount and accessibility of nectar sugars. J Appl Entomol 141: 561-573.

Markell SG, Harveson RM, Block CC, Gulya TJ. 2015. Sunflower diseases. In: Martínez-Force E, Dunford NT, Salas JJ, eds. Sunflower: Chemistry, Production, Processing, and Utilization. Monograph Series on Oilseeds. Urbana (Illinois): AOCS Press, pp. 93-128.

Martre P, Quilot-Turion B, Luquet D, Ould-Sidi M, Chenu K, Debaeke P. 2015. Model assisted phenotyping and ideotype design. In: Calderini D, Sadras VO, eds. Crop Physiology. Applications for Genetic Improvement and Agronomy, 2nd ed., Academic Press, pp. 349-373. 
Masalia RR, Temme AA, De Leon Torralba N, Burke JM. 2018. Multiple genomic regions influence root morphology and seedling growth in cultivated sunflower (Helianthus annuus L.) under well-watered and water-limited conditions. PLoS One 13 (9): e0204279.

Mangin B, Casadebaig P, Cadic E, et al. 2017. Genetic control of plasticity of oil yield for combined abiotic stresses using a joint approach of crop modelling and genome-wide association. Plant Cell Environ 40: 2276-2291.

Maury P, Mojayad F, Berger M, Planchon C. 1996. Photosynthesis response to drought acclimation in two sunflower genotypes. Physiol Plant 98: 57-66.

Mazzoncini M, Bàrberi P, Belloni P, Cerrai D, Antichi D. 2006. Sunflower under conventional and organic farming systems: results from a long term experiment in Central Italy. Asp Appl Biol 79: $125-129$.

Merrill SD, Tanaka DL, Hanson JD. 2002. Root length growth of eight crop species in Haplustoll soils. Soil Sci Soc Am J 66: 913-923.

Mercau JL, Sadras VO, Satorre EH, et al. 2001. On-farm assessment of regional and seasonal variation in sunflower yield in Argentina. Agric Syst 67: 83-103.

Merrien A, Grandin G. 1990. Comportement hydrique du tournesol : synthèse des essais «irrigation» 1983-88. In: Le tournesol et l'eau: adaptation à la sécheresse, réponse à l'irrigation. Paris: Éditions Cetiom, pp. 75-90.

Meynard JM, Debaeke P, Dejoux JF, Saulas P. 1997. Quelle sélection variétale pour une agriculture durable? OCL 4: 426-430.

Miladinović D, Hladni N, Radanović A, Jocić S, Cvejić S. 2019. Sunflower and climate change: Possibilities of adaptation through breeding and genomic selection. In: Kole C, ed. Genomic Designing of Climate-Smart Oilseed Crops. Springer Nature Switzerland AG, pp. 173-238.

Mohler CL, Johnson SE. 2009. Crop rotation on organic farms: a planning manual. Ithaca, NY: Cooperative Extension, Natural Resource, Agriculture, and Engineering Service (NRAES).

Moriondo M, Bindi M. 2007. Impact of climate change on the phenology of typical Mediterranean crops. Ital J Agrometeorol 3: $5-12$.

Moriondo M, Giannakopoulos C, Bindi M. 2011. Climate change impact assessment: the role of climate extremes in crop yield simulation. Clim Change 104: 679-701.

Montemurro F, De Giorgio D. 2005. Quality and nitrogen use efficiency of sunflower grown at different nitrogen levels under Mediterranean conditions. J Plant Nutr 28: 335-350.

Mouillon P, Caldwell BA, Cordeau S, Pelzer CJ, Wayman S, Ryan MR. 2020. Crop density affects weed suppression in organically managed sunflower. Agron J 112: 450-457.

Murillo JM, Moreno F, Pelegrin F, Fernandez JE. 1998. Responses of sunflower to traditional and conservation tillage under rainfed conditions in southern Spain. Soil Tillage Res 49: 233-241.

Nabloussi A, Akhtouch B, Boujghagh M, El Asri M, El Fechtali M. 2008. Ichraq : première variété de tournesol d'automne au Maroc. In: Proc 17th Int Sunf Conf, ISA, Córdoba, Spain.

Nagarathna TK, Shadakshari YG, Ramakrishna Parama VR, Jagadish KS, Puttarangaswamy KT. 2012 Examination of root characters, isotope discrimination, physiological and morphological traits and their relationship used to identify the drought tolerant sunflower (Helianthus annuus L.) genotypes. Helia 35(56): 1-8.

Nehnevajova E, Herzig R, Federer G, Erismann KH, Schwitzguébel JP. 2005. Screening of sunflower cultivars for metal phytoextraction in a contaminated field prior to mutagenesis. Int J Phytoremed 7: 337 349.
Nicolson SW, Human HH. 2013. Chemical composition of the 'low quality' pollen of sunflower (Helianthus annuus, Asteraceae). Apidologie 44: 144-152.

Nielsen DC, Anderson RL, Bowman RA, Aiken RM, Vigil MF, Benjamin JG. 1999. Winter wheat and prose millet yield reduction due to sunflower in rotation. J Prod Agric 12: 193-197.

Nolasco SM, Aguirrezábal LAN, Lúquez J, Mateo C. 2006. Variability in oil tocopherol concentration and composition of traditional and high oleic sunflower hybrids (Helianthus annuus L.) in the Pampean region (Argentina). Grasas y Aceites 57: 260-269.

Oil World Annual. 2019. Vol. 1. Global analysis of all major oilseeds, oils and oilmeals: supply, demand and price outlook. ISTA Mielke Gmbh.

de Oliveira ACV, de Moraes A, Ribeiro MFS, et al. 2012. The effect of shading on yield of sunflower production in agroforestry system with eucalyptus. In: Proc. 2nd Int Symp Integrated CropLivestock Systems, Porto Alegre (Brazil).

Olowe VIO, Adeyemo AY. 2009. Enhanced crop productivity and compatibility through intercropping of sesame and sunflower varieties. Ann Appl Biol 155: 285-291.

Olowe VIO, Adebimpe OA. 2009. Intercropping sunflower with soyabeans enhances total crop productivity. Biological Agriculture and Horticulture 26: 365-377.

Onofri A, Tei F. 1994. Competitive ability and threshold levels of three broadleaf weed species in sunflower. Weed Res 34: 471-480.

Park CS, Marx GD, Moon YS, Wiesenborn D, Chang KC, Hofman VL. 1997. Alternative uses of sunflower. In: Schneiter AA, ed. Sunflower technology and production. Agronomy Monographs 35. Madison, Wisconsin: ASA, CSSA, SSSA, pp. 765-807.

Pereyra-Irujo GA, Velazquez L, Granier C, Aguirrezabal LAN. 2007. A method for drought tolerance screening in sunflower. Plant Breed 126: 445-448.

Pereyra-Irujo GA, Velazquez L, Lechner L, Aguirrezabal LAN. 2008. Genetic variability for leaf growth rate and duration under water deficit in sunflower: analysis of responses at cell, organ, and plant level. J Exp Bot 59: 2221-2232.

Peyronnet C, Lacampagne JP, Le Casdre P, Pressenda F. 2014. Les sources de protéines dans l'alimentation du bétail en France : la place des oléoprotéagineux. OCL 21(4): D402.

Picheny V, Trépos R, Casadebaig P. 2017a. Optimization of black-b ox models with uncertain climatic inputs - Application to sunflower ideotype design. PLoS One 12(5): e0176815.

Picheny V, Casadebaig P, Trépos R, et al. 2017b. Using numerical plant models and phenotypic correlation space to design achievable ideotypes. Plant Cell Environ 40: 1926-1939.

Pilorgé E. 2020. Sunflower in the global vegetable oil system: situation, specificities and perspectives. OCL 27: 34 .

Pinochet X, Debaeke P, Casadebaig P, Mestries E, Langlade N. 2020. SUNFLO : un modèle au service de l'amélioration du tournesol. Persp Agric 480: 55-57.

Ploschuk EL, Hall AJ. 1995. Capitulum position in sunflower affects grain temperature and duration of grain filling. Field Crops Res 44: 111-117.

Porter PM, Crookston RK, Ford JH, Huggins DR, Lueschen WE. 1997. Interrupting yield depression in monoculture corn: comparative effectiveness of grasses and dicots. Agron J 89: 247-250.

Portlas ZM, Tetlie JR, Prischmann-Voldseth D, Hulk BS, Prasifka JR. 2018. Variation in floret size explains differences in wild bee visitation to cultivated sunflowers. Plant Genetic ResourcesCharacterization and Utilization 16: 498-503.

Prasifka JR, Mallinger RE, Portlas ZM, et al. 2018. Using nectarrelated traits to enhance crop-pollinator interactions. Front Plant Sci 9: 812 . 
Quilot-Turion B, Génard M, Valsesia P, Memmah MM. 2016. Optimization of allelic combinations controlling parameters of a peach quality model. Front Plant Sci 7: 1873.

Quiroz F, Molas AC, Rojo R, Fernandez JP, Escande A. 2008. Effects of no tillage and genetic resistance on sunflower wilt by Verticillium dahliae. Soil Tillage Res 99: 66-75.

Radanielson AM, Lecoeur J, Christophe A, Guilioni L. 2012. Use of water extraction variability to screen for sunflower genotypes well adapted to soil water limitation. Funct Plant Biol 39: 999-1008.

Rachidi F, Kirkham MB, Stone LR, Kanemasu ET. 1993. Soil water depletion by sunflower and sorghum under rainfed conditions. Agric Water Manage 24: 49-62.

Ramshe DG, Umrani NK, Walujkar RB, Tambe TB. 1994. Effect of association of tree species on grain production of arable rainyseason crops. Ind J Agron 39: 188-192.

Ramstein GP, Jensen SE, Buckler ES. 2019. Breaking the curse of dimensionality to identify causal variants in breeding 4 . Theor Appl Genet 132: 559-567.

Rauf S. 2008. Breeding sunflower (Helianthus annuus L.) for drought tolerance. Commun Biomet Crop Sci 3: 29-44.

Rauf S, Sadaqat HA, Ahmad R, Khan IA. 2009. Genetics of root characteristics in sunflower (Helianthus annuus L.) under contrasting water regimes. Ind J. Plant Physiol 14: 319-327.

Rizwan M, Ali S, Rizvi H, et al. 2016. Phytomanagement of heavy metals in contaminated soils using sunflower: a review. Crit Rev Env Sci Technol 46: 1498-1528.

Robinson RG. 1984. Sunflower for strip, row, and relay intercropping. Agron J 76: 43-47.

Rodriguez AT, Brihet JM. 2019. El girasol recupera con área y tecnología. Cuáles son los aspectos claves? In: $7^{\circ}$ Congreso Argentino de Girasol, ASAGIR, UBA, Buenos Aires (Argentina), 2 Julio 2019.

Rodriguez-Lizana A, Carbonell R, Gonzalez P, Ordonez R. 2010. N, P and $\mathrm{K}$ released by the field decomposition of residues of a peawheat-sunflower rotation. Nutr Cycl Agroecosyst 87: 199-208.

Rondanini D, Savin R, Hall AJ. 2003. Dynamics of fruit growth and oil quality of sunflower (Helianthus annuus L) exposed to brief intervals of high temperature during grain filling. Field Crops Res 83: 79-90.

Rondanini D, Mantese A, Savin R, Hall AJ. 2006. Responses of sunflower yield and grain quality to alternating day/night high temperature regimes during grain filling: effects of timing, duration and intensity of exposure to stress. Field Crops Res 96: 48-62.

Ross F. 2016. Sunflower double cropping after winter crop: sowing date and cycle length. In: Proc 19th Int Sunf Conf, ISA, Edirne, Turkey.

Ryan MR, Smith RG, Mortensen DA, et al. 2009. Weed-crop competition relationships differ between organic and conventional cropping systems. Weed Res 49: 572-580.

Sadras V, Connor DJ. 1991. Physiological basis of the response of harvest index to the fraction of water transpired after anthesis: A simple model to estimate harvest index for determinate species. Field Crops Res 26: 227-239.

Sadras VO, Whitfield DM, Connor DJ. 1991. Regulation of evapotranspiration and its partitioning between transpiration and soil evaporation by sunflower crops. A comparison between hybrids of different stature. Field Crops Res 28: 17-37.

Sadras VO, Echarte L, Andrade FH. 2000. Profiles of leaf senescence during reproductive growth of sunflower and maize. Ann Bot 85: $185-195$.

Salera E. 1992. Influence of sowing period on production response of sunflower in catch crop growing. In: Proc 12th Int Sunf Conf, ISA, Pisa, Italy.
Sanghera GS, Wani SH, Hussain W, Singh N. 2011. Engineering cold stress tolerance in crop plants. Curr Genom 12: 30-43.

Scapinelli A, Deina FR, Valadao DD, Assis Valadao FC, Pereira LB. 2016. Root system and productive components of the sunflower in a compacted soil. Bragantia 75: 474-486.

Schneiter AA, Miller JF. 1981. Description of sunflower growth stages. Crop Sci 21: 901-903.

Seddaiu G, Iocola I, Farina R, Orsini R, Iezzi G, Roggero PP. 2016. Long-term effects of tillage practices and $\mathrm{N}$ fertilization in rainfed Mediterranean cropping systems: durum wheat, sunflower and maize grain yield. Eur J Agron 77: 166-178.

Seiler GJ. 1994. Primary and lateral root elongation of sunflower seedlings. Environ Exp Bot 34: 409-418.

Seiler GJ. 2008. Root growth of interspecific sunflower seedlings derived from wild perennial sunflower species. Can J Plant Sci 88: 705-712.

Seiler GJ. 2012. Utilization of wild Helianthus species in sunflower breeding. In: Škorić D, ed. Sunflower Genetics and Breeding International Monogram. Novi Sad, Serbia: Serbian Academy of Sciences and Arts, pp. 355-413.

Seiler GJ, Qi LL, Marek LF. 2017. Utilization of sunflower crop wild relatives for cultivated sunflower improvement. Crop Sci 57: 1-19.

Seufert V, Ramankutty N, Foley JA. 2012. Comparing the yields of organic and conventional agriculture. Nature 485: 229-232.

Sheaffer CC, McNemar JH, Clark NA. 1977. Potential of sunflowers for silage in double-cropping systems following small grains. Agron J 69: 543-546.

Silva HL, Trezzi MM, Marchese JA, et al. 2009. Determination of indicative species and comparison of sunflower genotypes as to their allelopathic potential. Planta Daninha 27: 655-663.

Silvestri N, Pampana S, Bonari E, Conti D. 2000. Evaluation of sunflower agro-economic performances in low-input cropping systems of Central Italy. In: Proc 15th Int Sunf Conf, ISA, Toulouse, France.

Škorić D. 2009. Sunflower breeding for resistance to abiotic stresses. Helia 32(50): 1-16.

Sobrado MA, Turner NC. 1986. Photosynthesis, dry matter accumulation and distribution in the wild sunflower Helianthus petiolaris and the cultivated sunflower Helianthus annuus as influenced by water deficits. Oecologia 69: 181-187.

Sojka RE, Arnold FB, Morrison III WH, Brusscher WJ. 1989. Effect of early and late planting on sunflower performance in the southeastern United States. Appl Agric Res 4: 37-46.

Soriano MA, Orgaz F, Villalobos FJ, Fereres E. 2004. Efficiency of water use of early plantings of sunflower. Eur J Agron 21: 465 476.

Stejskalová M, Konradyová V, Suchanová M, Kazda J. 2018. Is pollinator visitation of Helianthus annuus (sunflower) influenced by cultivar or pesticide treatment? Crop Protection 114: 83-89.

Stockdale EA, Lampkin NH, Hovi M, et al. 2001. Agronomic and environmental implications of organic farming systems. $A d v$ Agron 70: 261-327.

Stone LR, Goodrum DE, Schlegel AJ, Jaafar MN, Khan AH. 2001. Rooting front and water depletion depths in grain sorghum and sunflower. Agron J 93: 1105-1110.

Takami S, Turner NC, Rawson HM. 1981. Leaf expansion of four sunflower (Helianthus annuus L.) cultivars in relation to water deficits. I. Patterns during plant development. Plant Cell Environ 4: 399-407.

Tariq M, Ahmad S, Fahad S, et al. 2018. The impact of climate warming and crop management on phenology of sunflower-based cropping systems in Punjab, Pakistan. Agric For Meteorol 256: $270-282$. 
Terres Inovia. 2020. Tournesol : conseil variétal régionalisé pour les semis 2020. Available from http://www.myvar.fr/ (last consult: 2020/06/11).

Terzić S, Miklic V, Canak P. 2017. Review of 40 years of research carried out in Serbia on sunflower pollination. OCL 24(6): D608.

Terzić S, Boniface M-C, Marek L, et al. 2020. Gene banks for wild and cultivated sunflower genetic resources. OCL 27: 9.

Tetreault HM, Kawakami T, Ungerer MC, Levy C. 2016. Low temperature tolerance in the perennial sunflower Helianthus maximiliani. Am Midland Naturalist 175: 91-102.

Todesco M, Owens GL, Bercovich N, et al. 2020. Massive haplotypes underlie ecotypic differentiation in sunflowers. Nature 584: 602607.

Tomich TR, Rodrigues JAS, Gonçalves LC, Tomich RGP, Carvalho AU. 2003. Forage potential of sunflower cultivars produced in double-cropping system for silage. Arq Bras Med Vet Zootec 55: 756-762.

Torralba M, Fagerholm N, Burgess PJ, Moreno G, Plieninger T. 2016. Do European agroforestry systems enhance biodiversity and ecosystem services? A meta-analysis. Agric Ecosyst Env 230: $150-161$.

Tourvieille de Labrouhe D, Bordat A, Tourvieille J, et al. 2010. Impact of major gene resistance management for sunflower on fitness of Plasmopara halstedii (downy mildew) populations. $O C L$ 17(1): 56-64.

Tribouillois H, Cristante P, Estragnat A, et al. 2012. Is sunflowersoybean intercropping an efficient solution for increasing natural resources use efficiency and yield production? In: Proc 18th Int Sunf Conf, ISA, Mar del Plata, Argentina.

Trudgill DL, Squire GR, Thompson K. 2000. A thermal time basis for comparing the germination requirements of some British herbaceous plants. New Phytol 14: 107-114.

Tuck G, Glendining MJ, Smith P, House JI, Wattenbach M. 2006. The potential distribution of bioenergy crops in Europe under present and future climate. Biomass Bioenerg 30: 183-197.
Ullah R, Aslam Z, Khaliq A, Zahir ZA. 2018. Sunflower residue incorporation suppresses weeds, enhances soil properties and seed yield of spring-planted mung bean. Plant Daninha 36: e018176393.

Vannozi GP, Baldini M, Gomez-Sanchez D. 1999. Agronomic traits useful in sunflower for drought resistance. Helia 22(30): 97-124.

Vear F. 2016. Changes in sunflower breeding over the last fifty years. OCL - Oilseeds \& fats Crops and Lipids 23: D202.

Vear F, Bony H, Joubert G, Tourvieille de Labrouhe DT, Pauchet I, Pinochet X. 2003. 30 years of sunflower breeding in France. $O C L$ 10: 66-73.

Velázquez L, Alberdi I, Aguirrezábal L, Pereyra-Irujo G. 2012. Wilting contributes to genotypic differences in the response of transpiration rate to soil drying. In: Proc 18th Int Sunflower Conf, ISA, Mar del Plata and Balcarce, Argentina.

Villalobos FJ, Sadras VO, Soriano A. Fereres E. 1994. Planting density effects on dry matter partitioning and productivity of sunflower genotypes. Field Crops Res 36: 1-11.

Vincourt P, Carolo P. 2018. Alternative breeding processes: at which extent participatory breeding should modify the concept of ideotypes in plant breeding? OCL 25(6): D606.

Wanjari RH, Yaduraju NT, Ahuja KN. 2000. Critical period of weed competition in spring sunflower (Helianthus annuus L.). Ind $J$ Weed Sci 32: 17-20.

Warburton ML, Rauf S, Marek L, Hussain M, Ogunola O, Sanchez Gonzalez JJ. 2017. The use of crop wild relatives in maize and sunflower breeding. Crop Sci 57: 1227-1240.

Wien HC. 2008. Screening sunflower cultivars for reaction to daylength in flowering. Hort Sci 43: 1285-1286.

Zarch MJB, Mahmoodi S, Eslami SV. 2017. Evaluating the competitive ability of sunflower (Helianthus annuus L.) cultivars against tumble pigweed (Amaranthus albus L.) in Birjand region. Agroecology 9: 88-101.

Zimdahl RL, ed. 2004. Weed-crop competition: a review, 2nd ed. Blackwell Publishing.

Cite this article as: Debaeke P, Casadebaig P, Langlade NB. 2021. New challenges for sunflower ideotyping in changing environments and more ecological cropping systems. OCL 28: 29. 